\title{
6. DIAGENETIC CARBONATES FROM CASCADIA MARGIN: TEXTURES, CHEMICAL COMPOSITIONS, AND OXYGEN AND CARBON STABLE ISOTOPE SIGNATURES
}

\author{
A. Kopf, ${ }^{2}$ J.C. Sample, ${ }^{3}$ P. Bauer, ${ }^{2}$ J.H. Behrmann, ${ }^{2}$ and H. Erlenkeuser ${ }^{4}$
}

\begin{abstract}
Active fluid venting and carbonate formation occur in the accretionary prism in the Cascadia subduction zone off Vancouver Island and Oregon. Methane-derived authigenic carbonates are precipitated in the uppermost terrigenous sediments by subduction-induced dewatering. They can be divided into cemented silts and sands containing less than $10 \%$ carbonate cements and concretions composed partially or wholly of carbonate. Textures, chemical compositions, and carbon and oxygen isotope signatures of 64 specimens of mainly carbonate concretions from Ocean Drilling Program Sites 889/890, 891, and 892 were studied using different methods. Mineralogically, the carbonate cement consists of high-magnesian calcite, dolomite, and calcite with varying amounts of detrital constituents. Results from $\mathrm{x}$-ray fluorescence, $\mathrm{x}$-ray diffraction, and electron microprobe analyses suggest dominance of high magnesian calcite in most of the carbonate concretions. Complex carbonates and protodolomite to pure dolomite are found in minor amounts. Cemented sediments and concretions taken in the vicinity of a prominent fault zone at Site 892 show an almost pure calcitic composition and the most intense deformation of all material drilled in the Cascadia Margin. Concretion fragmentation is believed to be caused by both brecciation and hydrofracture from mechanical stress and lowered lithostatic load during upward migration of rocks and fluids along the fault plane. Strain evaluation based on distortions of initially homogeneous marker particle distributions (the Fry technique) obtained aspect ratios $\left(R_{f}\right)$ between 1.2 and 1.71 reflecting uniaxial shortening in the sediment as a response to compaction prior to carbonate formation. Compactional strains ( $e_{y}$, elongation parallel to core axis) are found to range from -0.17 to -0.42 and give evidence for significant settling of the sediment prior to concretion formation. Evidence for post-formational compaction, displacement of carbonate, or recrystallization incipient diagenesis could not be observed. Stable carbon and oxygen isotope signatures identify distinct groups of methane-derived carbonate concretions. Almost half of the examined concretions show variable carbon isotope signatures, ranging from $-12 \%$ to $-52 \%$ PDB (Peedee belemnite) with no systematic trend downhole. These carbonate concretions evidently reflect precipitation from thermogenic methane, probably with contributions of biogenic methane in minor amounts. A second set of samples is characterized by $\delta^{13} \mathrm{C}$ values between $-6 \%$ to $+24 \%$ PDB. Values between $-4 \%_{0}$ and $0 \%$ reflect marine carbonate precipitated from seawater. The substantial enrichment in ${ }^{13} \mathrm{C}$ is most likely caused by supply of $\mathrm{CO}_{2}$ evolved from fermentation in the sediment pile. Oxygen isotope ratios largely scatter around $\delta^{18} \mathrm{O}$ values for modern ocean water $(-1 \% \mathrm{c}$ to $+6 \%$ PDB). Exceptional "light" $\delta^{18} \mathrm{O}$ signatures with values ranging from $-11 \%$ to $-17 \%$ PDB were only found in the vicinity of a prominent fault zone at Site 892 . That depletion in ${ }^{18} \mathrm{O}$ may be explained by upward migration and channeled expulsion of warm fluids along the fault zone that are probably in isotopic disequilibrium with interstitial waters. Zonation patterns of $\mathrm{C}$ and $\mathrm{O}$ isotope ratios partly occur, showing depletion in ${ }^{13} \mathrm{C}$ and ${ }^{18} \mathrm{O}$ towards the centers of concretions. Isotopic gradients may have been caused by episodic supply of methane-rich fluid of different reservoirs, isotopic compositions, and/or temperature.
\end{abstract}

\section{INTRODUCTION}

The authigenic carbonates that were obtained during Ocean Drilling Program (ODP) Leg 146 from the Cascadia accretionary wedge enable us to clarify the relationship between the hydrogeologic processes in a convergent margin scenario and the formation and diagenesis of carbonate phases. Both poorly consolidated clastic sediments with mostly detrital carbonate (largely $<15 \%$ ) and firm carbonate concretions and cemented sandstones (between $25 \%$ and $90 \%$ authigenic carbonate) were known from earlier work on dredged Cascadia forearc sediments (e.g., Ritger et al., 1987; Kulm and Suess, 1990; Sample et al., 1993). Magnesian calcite and dolomite were dominantly precipitated in the uppermost Cascadia margin sediments, showing significant stable carbon and oxygen isotope ratios related to meth-

'Carson, B., Westbrook, G.K., Musgrave, R.J., and Suess, E. (Eds.), 1995. Proc. ODP. Sci. Results, 146 (Pt. 1): College Station, TX (Ocean Drilling Program).

${ }^{2}$ Institut für Geowissenschaften und Lithosphärenforschung, Universität Giessen, Senckenbergstraße 3, 35390 Giessen, Federal Republic of Germany.

${ }^{3}$ Department of Geological Sciences, California State University, 1250 Bellflower Blvd., Long Beach, CA 90840, U.S.A.

${ }^{4}$ Institut für Reine und Angewandte Kernphysik, Universität Kiel, Olshausenstraße 40-60, 24118 Kiel, Federal Republic of Germany. ane-derived fluid expulsion (Ritger et al., 1987; Kulm and Suess, 1990).

The tectonically-induced dewatering of accreted sediments and the expulsion of overpressured pore fluids to the ocean floor is the mechanism for accumulation of gas hydrates in the accretionary wedge (e.g., Kvenvolden and McMenamin, 1980; Kvenvolden and Barnard, 1983). Both high amounts of free gas, and pellets and crystals of gas hydrates cause bottom-simulating reflectors (BSRs) that are believed to indicate the base of gas hydrate stability. BSRs are recognized world-wide and elsewhere in the East Pacific (e.g., Kvenvolden and Kastner, 1990; Bangs et al., in press). Hydrocarbons (mainly methane) are transported both through permeable beds or along faults (Sample et al., 1993), or hydraulic fractures and microveins (Behrmann, 1991), and they can originate from different depths and related fluid reservoirs inside the accretionary prism (e.g., Sample et al., 1993; Sample and Kopf, this volume). Methane of both biogenic $\left(\delta^{13} \mathrm{C}=-70 \%\right.$ to $-90 \%$ PDB; see Rosenfeld and Silverman, $1959)$ and thermogenic origin $\left(\delta^{13} \mathrm{C}=-20 \%\right.$ to $-50 \%$ PDB; see $\mathrm{Vi}$ nogradov and Galimov, 1970) may upon oxidation form carbonates in oxic or anoxic environments (see Higgins and Quale, 1970; Reeburgh, 1980). Oxygen isotopic ratios of carbonates are controlled by both the oxygen isotope composition of the fluid from which the authigenic carbonates precipitate and by the temperature prevailing 
during precipitation. The oxygen-isotope fractionation in calcites in isotopic equilibrium with the fluid correlates with increasing temperature, as described by several authors (e.g., Clayton, 1961; Shackleton, 1974). For modern ocean water, with nominal temperatures of $-2^{\circ}$ to $+3^{\circ} \mathrm{C}$, the oxygen isotope composition of carbonates is expected to range between $+4.5 \%$ and $+3 \%$ PDB. Oxygen isotope signatures of carbonate resulting from microbial consumption of organic matter are also typically higher than $\delta^{18} \mathrm{O}$ from other carbonate cements (e.g., Ritger et al., 1987).

Carbonate precipitation occurs in response to decreasing solubility of $\mathrm{CO}_{2}$ during upward migration of fluids resulting from release of hydrostatic pressure, decrease in temperature, alkalinity of the fluid, and depth-related concentration changes of $\mathrm{Mg}^{2+}$ or $\mathrm{Ca}^{2+}$ in the fluids (Füchtbauer and Müller, 1977). Many processes such as bacterially mediated reactions, supply of meteoric water, hydrocarbons or organic matter, or subduction-related fluid expulsion control those and other parameters. As studies on deep-sea sediments revealed, precipitation of authigenic carbonate displays complex mineral associations with extensive cation-substitutions, leading to "complex carbonates" (e.g., Wada et al., 1982; Kelts and McKenzie, 1982). After the formation of authigenic carbonate near the sea floor, cementation and transformation of metastable phases (aragonite) occur as early diagenetic transformation (Füchtbauer and Müller, 1977). Recrystallization, dolomitization, and reprecipitation of carbonate represent incipient diagenesis.

The main objectives of this study are:

1. to document chemical and mineralogical variations in authigenic carbonate composition as a response to pore fluid chemistry. Electron microprobe analyses, petrographic studies on thin sections, $\mathrm{x}$-ray diffraction analyses, and $\mathrm{x}$-ray fluorescence analyses were carried out to determine the chemical and mineralogical composition of carbonate-rich sediments and rocks drilled at the Cascadia Margin;
2. to quantify strain as evidence for formation of carbonate concretions, either near the sediment-water interface or as earlyto late-diagenetic precipitates inside the sediment pile, preserving its stage of consolidation;

3. to estimate the contributions of biogenic and thermogenic methane supplied to carbonate formation via stable carbonisotopic ratios by mass spectrometry;

4. to show the variability in fluid supply (composition, reservoirs, and temperature) caused by zonation patterns of carbon and oxygen isotope ratios in both carbonate concretions and healed veins; and

5. to discuss data with respect to results of earlier research on carbonate-rich sediments from just below the sediment-water interface of the Cascadia forearc (e.g., Ritger et al., 1987; Kulm and Suess, 1990; Sample et al., 1993).

\section{GEOLOGICAL SETTING}

The Cascadia Margin has been a zone of convergent plate motion since the Eocene, as the Kula/Farallon and the Juan de Fuca Plates have been subducted obliquely beneath the North American Plate (e.g., Riddihough, 1984; Demets et al., 1990). This type of plate kinematics causes evolution of a complex interplay of sedimentation, structural evolution, diagenesis and fluid flow. Convergent motion in the Cascadia forearc results in sediment compaction, over-pressuring and expulsion of pore-fluids, and development of fault zones to structurally accommodate shortening and perhaps dewatering (e.g., Moore et al., 1990). Sediment offscraping and accretion takes place predominantly by landward-vergent thrusting along most of the Cascadia Margin. Leg 146 investigated the accretionary complex at the Cascadia continental margin by drilling at three sites near Vancouver Island and two sites off Oregon (Fig. 1).
Figure 1. Location map of the Cascadia continental margin, showing the convergence of the Juan de Fuca Plate relative to the North American Plate and the positions of sites drilled on Leg 146.

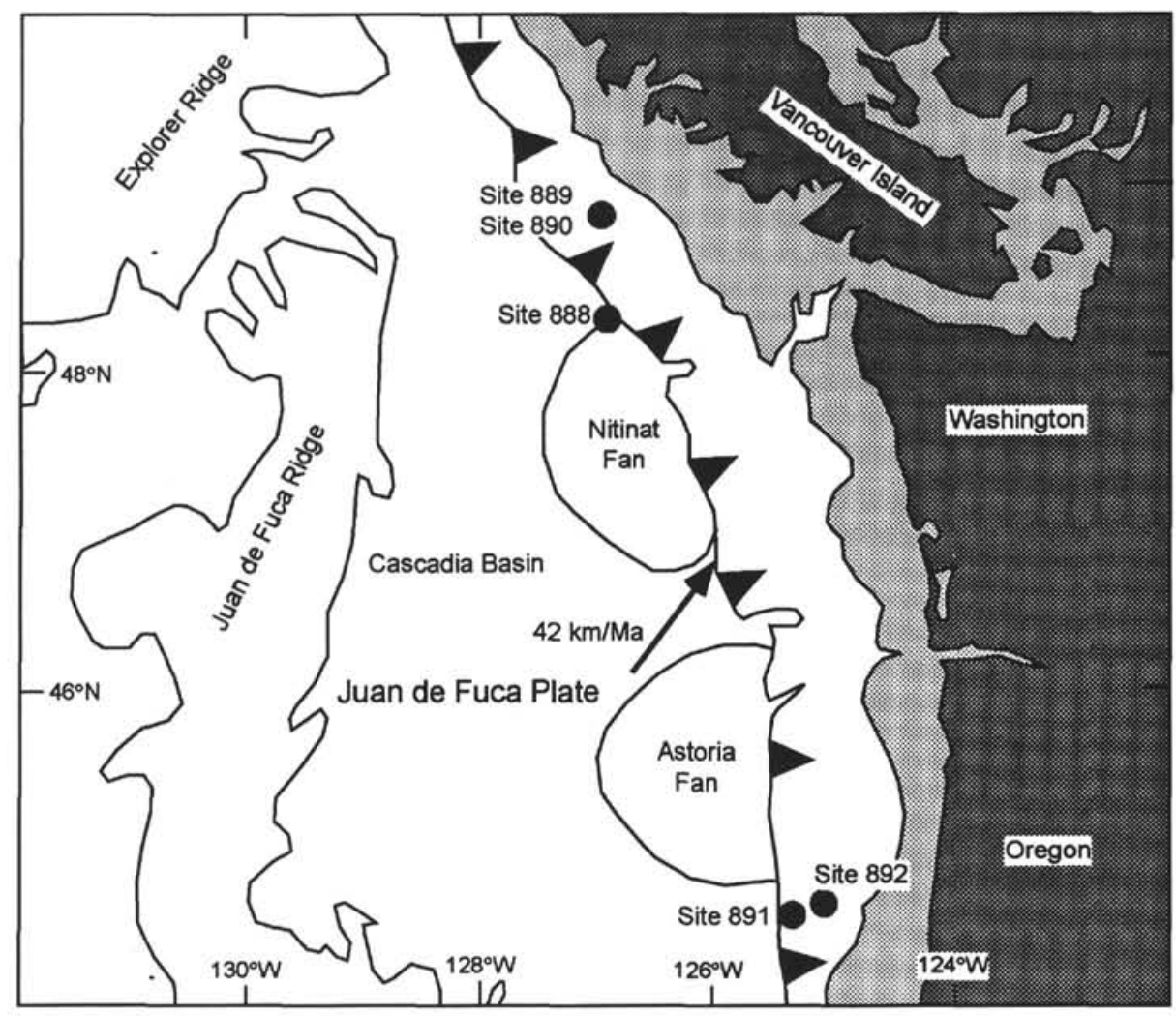


Off Vancouver Island, 3500 meters of largely hemipelagic sediments and terrigenous turbidites were accumulated on nearly 6 m.y.old oceanic crust (Fig. 2B). The basal part of the sediment pile is currently being subducted, while the hanging-wall material is frontally accreted. Fluid outflow off Vancouver Island is predominantly diffuse and stipulates vertical transport and accumulation of hydrocarbons of thermogenic or biogenic origin in the pore fluids (Carson et al., 1993). The occurrence of gas hydrates between 100 and $300 \mathrm{mbsf}$ and formation of a seismically imaged bottom-simulating reflector results from gas hydrate stability and the thermal structure of the Cascadia forearc (Hyndman and Davis, 1992).

The oceanic lithosphere that is subducted beneath the Oregon continental forearc is about $8 \mathrm{Ma}$ and carries up to $4000 \mathrm{~m}$ of marine sediments. Subduction-related deformation begins on the abyssal plain about $5 \mathrm{~km}$ seaward of the frontal thrust that is rooted within the sediment pile traveling on the downgoing Juan de Fuca Plate (Fig. $2 \mathrm{~A}$ ). A variety of seaward-facing thrusts, active backthrusts, and outof-sequence thrusts landward of the deformation front record the dynamics of the accretionary wedge. Dewatering dominantly occurs as channeled expulsion of pore fluids along faults in the Oregon accretionary complex (e.g., Tobin et al., 1993; Sample et al., 1993).

\section{DESCRIPTION OF SEDIMENTS AND TECTONIC STRUCTURE}

Although formation and variety of carbonate is the main focus of this study, a brief overview of drilled lithologies and the accompanying structural and tectonic observations should be given for Sites $889-892$ to provide a basis for further discussion of results. Site 888 west of the deformation front off Vancouver Island represented a sedimentary reference section on the northern edge of the Nitinat fan (Fig. 1). Turbiditic sediments were not taken into consideration because of the absence of carbonates.

Drilling Sites 889 and 890 into the accretionary prism off Vancouver Island (Fig. 1) recovered sediments ranging in age from Quaternary to late Pliocene with penetration extending to $386 \mathrm{mbsf}$. The hanging-wall material is interpreted as undeformed slope and slope basin deposits of late Quaternary age consisting of clayey silts, fine sands, and diagenetic carbonates (Westbrook, Carson, Musgrave, et al., 1994). The largely turbidites and hemipelagites are unlithified and subhorizontally bedded. Below $128 \mathrm{mbsf}$ to terminal depth a distinct progressive increase in both induration and intensity of deformation is evident. Firm clayey silts are thought to have formed in an abyssal plain environment and have been fragmented into subangular pieces afterwards during accretion (Westbrook, Carson, Musgrave, et al., 1994). A domain of steeply dipping beds $\left(40^{\circ}-70^{\circ}\right.$ at $104-127$ mbsf) is underlain by silts with moderately inclined bedding and contains shear fractures, deformation bands, and stratal disruption. Diagenetic carbonates are consistently present throughout the entire stratigraphic column and are concentrated in the interval between $150-350 \mathrm{mbsf}$. Carbonate is both of detrital origin and precipitated as spherical concretions. Variable amounts of glaucony (both pelletal and as grain coating) are found below $300 \mathrm{mbsf}$ to terminal depth at 386 mbsf (Westbrook, Carson, Musgrave, et al., 1994). The 225 mbsf depth of the BSR at Hole $889 \mathrm{~B}$ is derived from logging data and temperature measurements on board.

Site 891 lies on the westernmost ridge of the Oregon continental margin (Fig. 1). Drill-bits cored the upper portion (491 mbsf) of a 3km-thick seismic section of layered sediments (Fig. 2A). The dominantly clayey silts and fine to medium sands yield late Quaternary ages and similar compositions and textures throughout the stratigraphic column. The position on the lower slope of the accretionary complex, the post-middle Pleistocene ages, and composition of sediments suggest accumulation as proximal deposits on the Astoria Fan prior to uplift. The hanging-wall section (0-200 mbsf) is characterized by turbidites showing convolute- and cross-lamination, moderately tilted beds, and sparsely developed deformation bands. Down to $375 \mathrm{mbsf}$, where a prominent fault zone with scaly fabrics was penetrated, a marked increase in induration is found (Westbrook, Carson, Musgrave, et al., 1994). Firm silts are fragmented into pieces and show a bedding-plane parallel compaction fabric and occurrence of pervasive spaced fracturing. Another fault zone with shear fabrics, scaly foliation and polished and slickenslided surfaces was recognized at $263 \mathrm{mbsf}$. The frontal thrust was penetrated at about $368-375$ mbsf (Westbrook, Carson, Musgrave, et al., 1994). Drilling Site 891 revealed the common tectonostratigraphy of accretionary prisms, with either undeformed sediments or even near-surface slump folding underlain by intensely sheared and fragmented "broken formation" (cf. Hsü, 1968). The fault zone at the base of the broken formation is interpreted as the frontal thrust because sediments below $383 \mathrm{mbsf}$ are less indurated and less strained. Carbonate concretions and carbonate-cemented silts occur throughout the entire section.

Site 892 is located on the western flank of the second ridge of the Oregon accretionary wedge approximately $16 \mathrm{~km}$ landward of Site 891 (Figs. 1 and 2B). A sequence of dark to very dark gray finegrained, late Pliocene sediments of mainly terrigenous and hemipelagic clayey silt and silty clay were recognized throughout the entire hole to terminal depth of $176.5 \mathrm{mbsf}$ (Fig. 3). On the basis of structural characteristics the cored interval can be divided into three domains. Below a fault zone at the base of the hanging-wall section, which has moderately dipping beds of silt interbedded with fine sand at $52 \mathrm{mbsf}$, subhorizontal bedding and fracturing are observed. In the interval from 62-67 mbsf, shear bands and stratal disruption characterize another prominent fault zone (Fig. 3). The downhole increase in veins and scaly fabrics culminates in a strongly developed faultzone fabric with intervals of intense shearing and mélange fabrics below 106 mbsf. Carbonate occurred as patches, cemented silts, nannofossil oozes, and as concretions with different degrees of induration and random distribution throughout the entire sedimentary column of Site 892. The BSR is located at about 72 mbsf (Westbrook, Carson, Musgrave, et al., 1994).

\section{METHODS Sample Preparation}

Samples were taken oriented (soft sediments) or picked as discrete carbonate concretions aboard JOIDES Resolution. Both wet sediments and concretions were freeze dried at a minimal temperature of $-30^{\circ} \mathrm{C}$ immediately after Leg 146 ended. Afterwards, they were impregnated with epoxy resin (resin: Glycidether 162, Deutsche Shell Chemie; hardener: Laromin C620, BASF) and cut dry and parallel to the core axis, if possible. The cut surfaces were again impregnated with resin and then ground carefully with 400,800, and 1200 grit silicon carbide and diamond paste until all saw marks were removed. The ground surface of one of the subsamples was then mounted on a thin-section slide, ground to $40-60 \mu \mathrm{m}$ thickness, and then diamond polished for electron microprobe analyses. Afterwards ultra-thin sections ( $1-5 \mu \mathrm{m}$ thick) were produced from these specimens for optical petrography. The remaining half of each sample was pulverized using an agate mortar and pestle and an agate ball mill for $\mathrm{X}$-ray fluorescence analyses and $\mathrm{x}$-ray diffraction analyses.

\section{Optical Petrography and Fabric Quantification}

Sixty-four thin sections of both muds and carbonate concretions were studied and described petrographically. Additionally, strain estimations were obtained using two different approaches. Detrital components observed in the concretions were marked to quantify the 
fabric in the two dimensions of the thin section. This fabric analysis (described in detail in Behrmann and Kopf, 1993) uses the simple graphical method of Fry (1979; see also Ramsay and Huber, 1983) and the PODI technique (Unzog, 1990) to determine the distortion of an initially statistically homogeneous distribution of marker particles (diatom shells, glaucony spherules, opaques). A computer program evaluates the directional differences of marker particle spacings for strain. The axial ratio $\left(R_{f}\right)$ of the resulting strain ellipse is read visually from a Fry plot, and mathematically from the amplitude of a sine function derived from the population of marker particle spacings by a least-squares fit.

\section{Electron Microprobe Analysis}

Carbonate analyses were performed using a Cameca SX 50 electron microprobe (mode, wavelength dispersive; crystal, LiF, PET, and TAP; accelerating voltage, $20 \mathrm{KeV}$; beam current, $5 \mathrm{nA}$; magnification, $10000 \times$ ). 40 - to $60-\mu \mathrm{m}$-thick thin sections were polished with diamond paste and were carbon coated. Measurements were car- ried out with 2.8-3.3 nA specimen current and corrected against different carbon-coated carbonate standards. Determinations of $\mathrm{Mn}, \mathrm{Ba}$, $\mathrm{Mg}, \mathrm{Ca}, \mathrm{Pb}$, and $\mathrm{Sr}$ were corrected using the Taylor standard, while $\mathrm{Fe}$ and $\mathrm{Zn}$ were corrected using the Astimex standard.

\section{X-ray Fluorescence Analysis}

Freeze-dried samples weighing about $3 \mathrm{~g}$ were crushed and pulverized using an agate mortar and pestle and an agate ball mill. Determinations were made on pressed-powder pellets prepared by adding 3 drops of polyvinyl alcohol binder into an aluminum cap and pressing with $3 \mathrm{MPa}$ of pressure. Eleven major oxides $\left(\mathrm{SiO}_{2}, \mathrm{CaO}\right.$, $\mathrm{Al}_{2} \mathrm{O}_{3}, \mathrm{MnO}, \mathrm{MgO}, \mathrm{TiO}_{2}, \mathrm{~K}_{2} \mathrm{O}, \mathrm{Na}_{2} \mathrm{O}, \mathrm{P}_{2} \mathrm{O}_{5}, \mathrm{Fe}_{2} \mathrm{O}_{3}, \mathrm{SO}_{2}$ ) and twelve trace-elements ( $\mathrm{Sr}, \mathrm{Rb}, \mathrm{Y}, \mathrm{Nb}, \mathrm{Cr}, \mathrm{Ni}, \mathrm{V}, \mathrm{Cu}, \mathrm{Zn}, \mathrm{Zr}, \mathrm{Th}, \mathrm{U})$ were determined by $\mathrm{x}$-ray fluorescence, using a fully-automated wavelengthdispersive Siemens SRS 303 AS x-ray spectrometer, following the technique outlined by Norrish and Hutton (1969). Accuracy and precision of the method was monitored by including masked standards with each run of samples. Possible analytical error of the procedure
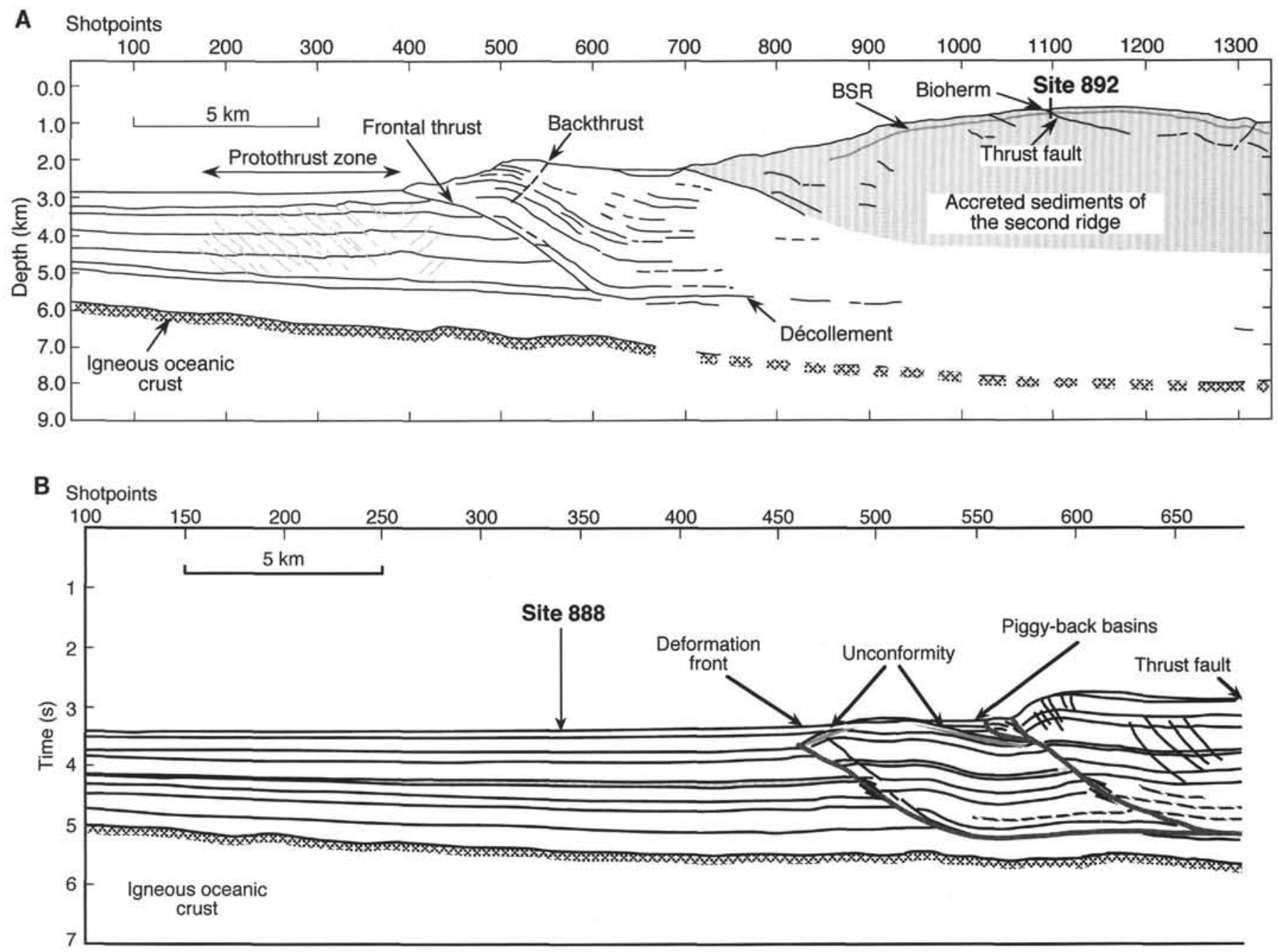

Figure 2. Line drawings of cross sections through Vancouver Island and the Oregon Margin. A. Line drawing of a cross section through the Central Oregon continental margin (seismic reflection line OR 9). Site 891 is located between the deformation front and the first ridge on the outer slope, and Site 892 was drilled at the top of the second ridge east of the foot of the continental slope off of Oregon (after MacKay et al., 1992). B. Line drawing of seismic reflection line 89-08 of the Cascadia accretionary complex at Vancouver Island, showing the location of Sites 888 and 889 . Seismically incoherent accretionary deposits and overlying bedded sediments of the mid slope are underlain by thrust sheets of the lower slope and undeformed Cascadia Basin deposits to the southwest (after Carson, Westbrook, Musgrave, et al., 1993). 
is about $1.5 \%$ (relative to reported values) for all elements. Matrix effects were corrected using a computer program for major elements and the Rhodium-Compton peak for the trace elements. The threshold of tolerance for the $\mathrm{CaO}$ content that was found for the first standard measurements was exceeded by most of the analyzed samples. The tolerances of the applied calibration curves were: $\mathrm{Si}, 39-75 ; \mathrm{Ti}$, $0.05-3.5 ; \mathrm{Al}, 0.5-18 ; \mathrm{Fe}, 0.5-17 ; \mathrm{Mn}, 0.01-0.3 ; \mathrm{Mg}, 0.1-40 ; \mathrm{Ca}, 0$ 14 ; Na, 0.8-8; K, 0.1-15; P, 0.01-1.3 (all wt\%); Sr, 10-4000 (ppm).

Because of high carbonate content, samples were diluted with a rock standard of defined composition (KTB gneiss; cf. Müller and Mingram, 1993). Determinations of $\mathrm{CO}_{2}$ and $\mathrm{H}_{2} \mathrm{O}$ were made using a LECO CS-125 gas chromatograph and a LECO RC-412 infraredspectrometer. The specimens were combusted to determine the amount of $\mathrm{H}_{2} \mathrm{O}, \mathrm{CO}_{2}$, and total carbon that are used to correct XRF data. Combined with XRF analyses and XRD analyses, these determinations allow calculations of the $\mathrm{Ca} / \mathrm{Mg}$ ratio under simplifying assumptions (see below).

\section{X-ray Diffraction Analysis}

X-ray diffraction patterns were determined for twenty-one pressed-powder pellets of pulverized carbonate concretions. Measurements were made using a Semens DIFFRAC D501 diffractometer. X-ray diffraction patterns were scanned from $20^{\circ}$ to $40^{\circ} 2 \theta$ at $0.02 \% \mathrm{sec}$, using $40 \mathrm{kV}$ accelerating voltage and $30 \mathrm{~mA}$ current with a copper $k \alpha$ source (1.5405 $\AA$ wave length). Peak heights in the region of $3.02 \AA$ and $2.81 \AA$ (first and second signal for $\mathrm{d}_{104}$ ) were used to determine presence and amount of calcite, $3.40 \AA$ and $1.99 \AA$ were used to characterize aragonite, and $2.89 \AA$ and $1.73 \AA$ were used to estimate dolomite. The ankerite reflections are located close to those of dolomite, with a slight shift of the second peak at $1.80 \AA$. Magnesian calcite is characterized by the shift of the calcite 104 peak toward dolomite, where displacement of $\mathrm{d}_{104}$ allows to calculate the content of $\mathrm{MgCO}_{3}$ (Goldsmith et al., 1961). The XRD method tends to underestimate the carbonate content, but the method is suitable for comparative studies of variable carbonate abundance. Combined with absolute values for $\mathrm{CaO}, \mathrm{MgO}$, and $\mathrm{CO}_{2}$ determined by XRF, absolute contents could be estimated roughly.

\section{Stable Isotope Mass Spectrometry}

Carbonate required for mass spectrometry analyses was obtained from freeze-dried carbonate concretions and carbonate-cemented veins inside soft sediments using a micro drill. Measurements were taken from $12 \mathrm{mg}$ of rock powder from each sample. The isotopic analyses $\left(\delta^{18} \mathrm{O}, \delta^{13} \mathrm{C}\right)$ of mainly micritic carbonate concretions were made using an automated Carbo Kiel $\mathrm{CO}_{2}$ preparation device coupled with a Finnigan MAT 251 mass-spectrometer, yielding data unattended carbonate-to- $\mathrm{CO}_{2}$ conversion and stable isotope analysis. Carbonate was reacted with $100 \% \mathrm{H}_{3} \mathrm{PO}_{4}$ at $73^{\circ} \mathrm{C}$, under vacuum. Calibration against the PDB-scale (Craig, 1957) is established via the NBS 19 and NBS 20 international carbonate isotope standards. Total reproducibility, given in the \%o-units of the usual $\delta$-scale, is $\pm 0.04 \%$ o for $\delta^{13} \mathrm{C}$ and $\pm 0.08 \%$ or for $\delta^{18} \mathrm{O}$. Reproducibility for $\delta^{18} \mathrm{O}$ may be poorer for the range outside $+10 \%$ and $-10 \%$.

\section{DATA}

\section{Sediment Composition}

Twenty-four specimens cored during Leg 146 were indurated to very hard carbonate concretions while the remaining samples were soft sediments (cf. Fig. 3). Description of sediments is summarized for Sites $889 / 890,891$, and 892 . Generally, three lithologies can be identified: muds and mudstones, sand and sandstones, and carbonate concretions. Amounts of mineral fractions are estimated visually.

Muds and mudstones are rarely indurated and consist of largely clayey silt to silty clay with interbedded sandy material. The clayey matrix of dominantly smectite, illite, chlorite, and carbonate is micritic to sparitic ( $<4$ to $50 \mu \mathrm{m}$ in grain size), and contains randomly distributed quartz, lithic fragments, or carbonatic detritus (both shells of organisms or authigenic minerals) up to $0.5 \mathrm{~mm}$ in size. Clay minerals (up to $35 \mathrm{vol} \%$ ) show partly preferred orientations. Mono- and polycrystalline quartz grains are up to $300-400 \mu \mathrm{m}$ in size and constitute about $15-20 \mathrm{vol} \%$ of the rock. Feldspar up to $300 \mu \mathrm{m}$ in size consists of alkali feldspar, which is often partially altered to sericite, and plagioclase with polysynthetic twinning, both with contents up to

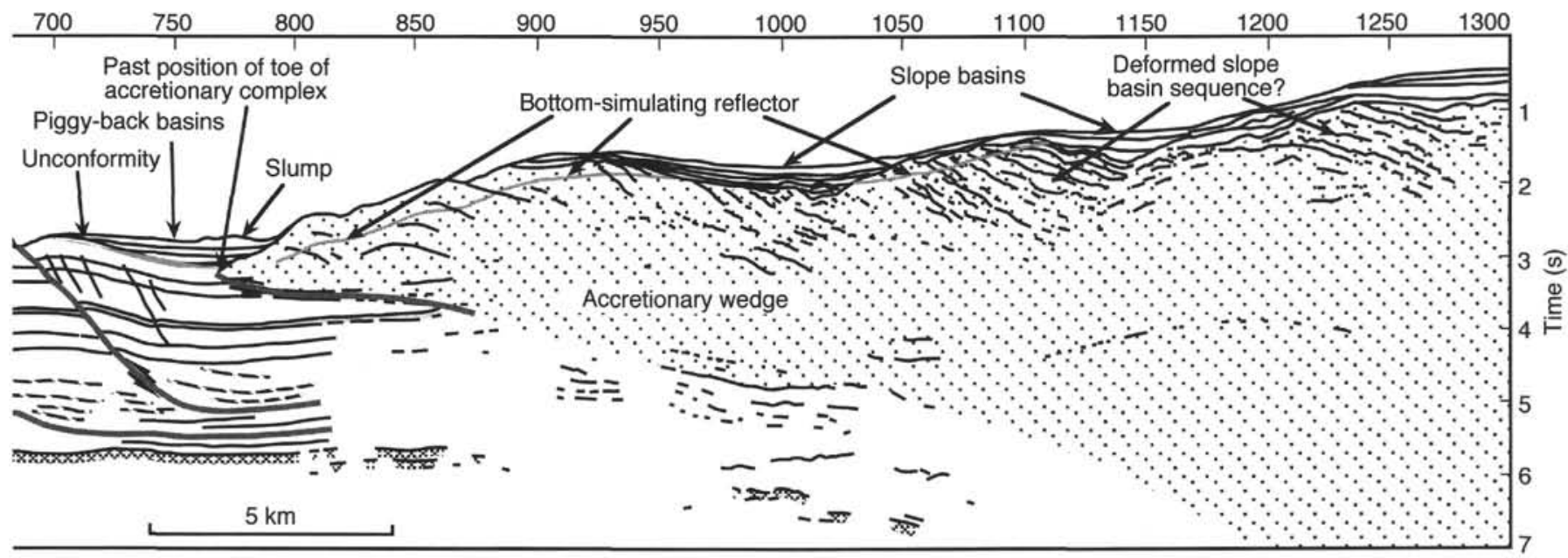

Figure 2 (continued). 


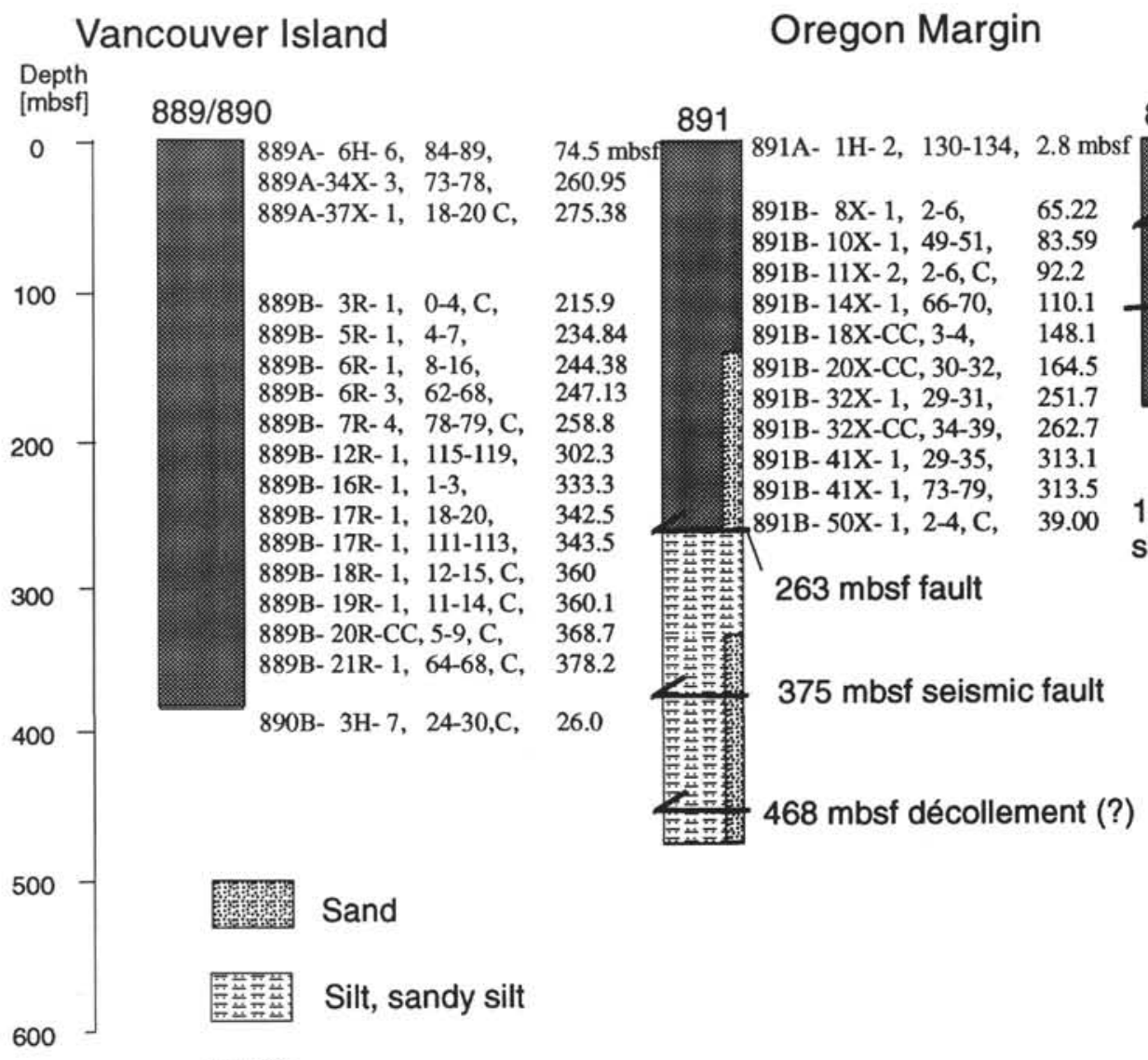

Clay, clayey silt, silty clay
892

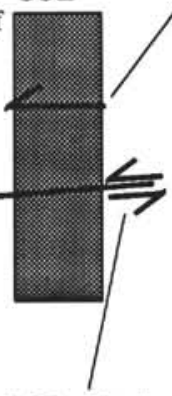

105 mbsf shear zone
62-67 fault zone

892A- 3X-1, $115-120, \quad 20.15 \mathrm{mbsf}$ $892 \mathrm{~A}-3 \mathrm{X}-2,99-101, \mathrm{C}, 21.5$ $892 \mathrm{~A}-3 \mathrm{X}-3, \quad 13-17, \quad 21.9$ $892 \mathrm{~A}-4 \mathrm{X}-1,4-5, \mathrm{C}, \quad 28.5$ 892A- $6 \mathrm{X}-1,63-67, \quad 39.6$ $892 \mathrm{~A}-6 \mathrm{X}-3, \quad 27-29, \quad 42.3$ $892 \mathrm{~A}-6 \mathrm{X}-3, \quad 51-56, \quad 42.5$ 892A- 6X-CC, 18-21, C, 45.7 892A- 6X-CC, 21-23, C, 45.7 $892 \mathrm{~A}-7 \mathrm{X}-3,10-14, \quad 51.6$ $892 \mathrm{~A}-7 \mathrm{X}-3,62-66, \quad 52.1$ $892 \mathrm{~A}-7 \mathrm{X}-3, \quad 147-150, \quad 52.9$ $892 \mathrm{~A}-7 \mathrm{X}-3,150-152, \mathrm{C}, 53.0$ $892 \mathrm{~A}-7 \mathrm{X}-5,138-142, \quad 56$ 892A- 9X-1, 13-15, 67.6 $892 \mathrm{~A}-9 \mathrm{X}-1,22-24, \quad 67.7$ 892A-13X-1, 9-14, $\quad 97.1$ 892A-15X-1, 2-3, C, $\quad 116$ 892A-15X-CC, 20-22, 117.2 892A-20X-1, 3-5, $\quad 163.5$ 892A-21X-1, 0-24, C, 173

$892 \mathrm{D}-4 \mathrm{X}-1,0-2, \mathrm{C}, \quad 27.5$ 892D- 6X-3, 69-74, 49.9 892D- 6X-3, 83-88, $\quad 50.1$ 892D- $6 \mathrm{X}-3,103-105, \mathrm{C}, 50.3$ 892D- 6X-3, 107-112, C, 50.3 892D- 8X-CC, 16-21, 66.7 892D- 8X-CC, 20-22, $\quad 66.7$ 892D- 8X-CC, 32-37, 66.9 892D-10X- $5, \quad 91-93, \quad 106.1$ 892D-12X-1, 136-141, 120.36 892D-12X- $2, \quad 142-144, \quad 121.9$

$892 \mathrm{E}-1 \mathrm{X}-1,74-76, \mathrm{C}, \quad 1.0$ 892E- $1 \mathrm{X}-2, \quad 80-82 \quad 1.06$

Figure 3. Graphic representation of major lithologies and main tectonic features of Sites 888, 889/890, 891, and 892. A list of studied samples for Sites 889/890, 891 , and 892 is given including the depth for each specimen.

$15 \mathrm{vol} \%$. Glaucony as spherules and grains up to $600 \mu \mathrm{m}$ is mainly observed in sediments from Sites 889 and 892 and is believed to have formed authigenically (Westbrook, Carson, Musgrave, et al., 1994). Organic matter and shells of microorganisms (diatoms, foraminifers) are found in most of the specimens with percentages varying from 10 to $40 \mathrm{vol} \%$. Disseminated fine-grained sulfides and oxides occur in trace amounts. Carbonate is found as detrital dolomite or calcite with contents below $5 \mathrm{vol} \%$ in most cases. Muds are mainly homogeneous showing faint lamination or brittle deformation with blocky textures. Fragmentation into subangular pieces, sub-scaly fabrics, and micromelanges are observed (see Clennell and Maltman, this volume).

Fine- to medium-grained sands are angular, poorly sorted, and are often interbedded with clayey silt/silty clay as patches or thin layers. Sedimentary structures are rarely preserved. Mono- and polycrystalline quartz grains with amounts up to $40 \%$ and grain sizes between $0.4 \mathrm{~mm}$ and $2 \mathrm{~mm}$ have angular grain shapes and are usually unstrained. Plagioclase with polysynthetic twinning and potassic feldspar are indicated by angular grain shapes and variable contents (10$25 \mathrm{vol} \%$ ). Carbonate is found as both dispersed matrix constituent and irregular shaped to idiomorphic grains of detrital origin, reaching contents of up to $10 \%$. Initial stages of cementation caused by carbonate precipitation are rarely observed. Accessory minerals are clinopyroxene, micas, amphibole, and epidote. Lithic fragments (10-20 vol\% on average) comprise as much as $50 \%$ of the sediment in coarser grained patches or laminae. Lithic fragments of volcanic, metamorphic, and sedimentary rocks are present (cf. Behrmann et al., this volume), as are well-rounded sedimentary lithic fragments of largely detrital quartz and feldspar grains (up to $1 \mathrm{~mm}$ in diameter) in a dark silty matrix that contains $0.1 \mathrm{~mm}$ to $0.4 \mathrm{~mm}$-wide fractures healed with calcite (e.g., Sample 146-892D-8X-CC, 16-21 cm, Pl. 1, Fig. 1).

Carbonate concretions studied are $2-4 \mathrm{~cm}$ in diameter and show different stages of cementation, with no systematic variation vs. depth. The initial, more or less dispersed, carbonate is followed by incipient crystallization of micritic carbonate and induration. According to textural features or size of mineral grains, concretions largely are homogeneous, showing microsparitic carbonate cements that tightly connect the detrital components. The finely dispersed carbonate of irregular shape is authigenically precipitated, rarely possessing different grain sizes $(5-40 \mu \mathrm{m})$ in the same thin section (e.g., Sample 146-892D-6X-3, 83-88 cm; Pl. 1, Fig 2). Quartz, feldspar (mainly plagioclase), and rare glaucony, pyrite, and clay minerals never exceed $10 \mathrm{vol} \%$. An estimated $70-80 \mathrm{vol} \%$ of carbonate minerals were observed in those micritic concretions. In some cases, concretions contain substantial portions of mainly detrital quartz and feldspar grains (Sample 146-889B-11X-2, 2-6 cm; Pl. 1, Fig. 3). Carbonate cements of those specimens are microsparitic with carbonate contents between $10 \%$ and $60 \%$ of the rock volume. Fragmented carbonate concretions are found at Site 892 (e.g., Sample 146-892A-21X-1, 0-24 cm; Pl. 1, Fig. 4), bearing fractures inside their homogeneous matrix that either are enclosed or reach the concretion surface. Fractures and veins are partially filled with carbonate, consisting of at least two generations of vein cement. Cement grew first inside the fractures or on the surface of the sub-grains after breakage, and forms 
a very fine-grained, $\mu$ m-thin coating. Spatial growth of fibrous carbonate into the free space starts subsequently upon these thin layers and achieves mineral grain sizes of up to $200 \mu \mathrm{m}$ (Pl. 1, Fig. 4). Approximately $5 \%-20 \%$ of the rock volume consists of fractures and veins based on thin-section observations.

\section{Textures and Strain Estimates}

Strain determinations were made on 19 samples of carbonate concretions from Sites 889B, 892A, and 892D using both the Fry and PODI methods. All samples were analyzed for the distortion of marker particle populations, but only fifteen yielded results of satisfactory quality using either the Fry or PODI technique, or both. Fragments of diatom or foraminifer shells (f), opaque material (o), pellets (p), and glaucony $(\mathrm{g})$ were used as marker particles. The number varied between 119 and 354 markers per counted interval of each sample. The results are listed in Table 1, and the data from Sample 146-892A$15 \mathrm{X}-1,2-3 \mathrm{~cm}$ with detrital glaucony as marker particles is shown as an example (Fig. 4). The fact that the central area of the Fry plot is not entirely devoid of points, plus the imperfect fit of the data to the sine function in the PODI diagram indicates that the initial marker particle distribution may not have been perfectly homogeneous.

Because of basic differences in the two methods, perfect Fry diagrams and imperfect PODI fitting (and vice versa) are found using the data derived from the specimens. Sample 146-892A-15X-1, 2-3 $\mathrm{cm}$ shows both a Fry plot with its center almost free of points and tolerable fit of data to the PODI cosine function. Values for $R_{f}$ in all samples range between 1.2 and 1.71 (Table 1). If the aspect ratio $\left(\mathrm{R}_{\mathrm{f}}\right)$ is taken to reflect the uniaxial shortening in the sediment as a response to compaction prior to carbonate cementation, then compactional vertical shortening strains $\left(\mathrm{e}_{2}\right)$ can be calculated (cf. Behrmann and Kopf, 1993). Values for $\mathrm{e}_{2}$ range from -0.17 to -0.42 , suggesting that in all cases the sediment had settled significantly prior to concretion formation. A systematic variation reflecting an increase in vertical shortening with depth is not evident.

Poor quality results are principally caused by three factors. As mentioned above, marker particles initially may not have been distributed homogeneously in the sediment section studied. Initial distribution cannot be verified afterwards, so that quality of the plot is the only criterion for exclusion. The second source of misleading strain

Table 1. Results of Fry and PODI strain analyses.

\begin{tabular}{|c|c|c|c|c|c|c|}
\hline $\begin{array}{l}\text { Core, section, } \\
\text { interval }(\mathrm{cm})\end{array}$ & $\begin{array}{l}\text { Depth } \\
\text { (mbsf) }\end{array}$ & Marker & $\begin{array}{c}R_{f} \\
\text { (Fry) }\end{array}$ & $\begin{array}{c}R_{f} \\
\text { (PODI) }\end{array}$ & $\begin{array}{c}\mathrm{e}_{2} \\
\text { (Fry) }\end{array}$ & $\begin{array}{c}\mathrm{e}_{\mathrm{z}} \\
\text { (PODI) }\end{array}$ \\
\hline \multicolumn{7}{|l|}{ 146-889B- } \\
\hline $3 R-1,0-4$ & 215.9 & Opaques & & 1.7 & & -0.41 \\
\hline $18 \mathrm{R}-1,2-5$ & 359.9 & Opaques & & 1.33 & & -0.24 \\
\hline $18 \mathrm{R}-1,2-5$ & 359.9 & Fóssils & & 1.47 & & -0.32 \\
\hline 20R-CC, 5-9 & 368.7 & Fossils & & 1.40 & & -0.29 \\
\hline $21 \mathrm{R}-1,64-68$ & 378.2 & Fossils & & 1.42 & & -0.30 \\
\hline \multicolumn{2}{|l|}{ 146-891B- } & & 1.2 & 1.44 & -0.17 & -0.31 \\
\hline \multicolumn{7}{|l|}{ 146-892A- } \\
\hline $6 \mathrm{X}-\mathrm{CC}, 18-21$ & 45.7 & Opaques & 1.53 & 1.33 & -0.35 & -0.25 \\
\hline $6 \mathrm{X}-\mathrm{CC}, 21-23$ & 45.7 & Glauconite & 1.55 & 1.57 & -0.35 & -0.36 \\
\hline $6 \mathrm{X}-\mathrm{CC}, 21-23$ & 45.7 & Fossils & 2.43 & & -0.59 & \\
\hline $7 X-3,150-152$ & 53.0 & Glauconite & & 1.49 & & -0.33 \\
\hline $15 X-1,2-3$ & 116.0 & Glauconite & 1.59 & 1.49 & -0.37 & -0.33 \\
\hline $15 X-C C, 20-22$ & 117.2 & Opaques & 1.62 & 1.71 & -0.38 & -0.42 \\
\hline $2 X-1,3-5$ & 163.5 & Opaques & 1.21 & 1.36 & -0.17 & -0.26 \\
\hline \multicolumn{7}{|l|}{ 146-892D- } \\
\hline $6 X-3,107-112$ & 50.3 & Opaques & 1.36 & & -0.26 & \\
\hline $6 X-3,107-112$ & 50.3 & Fossils & 2.17 & 1.53 & -0.54 & -0.35 \\
\hline
\end{tabular}

Notes: $R_{\mathrm{f}}$ (aspect ratio of the finite strain ellipse) is estimated visually (Fry) and calculated using the PODI algorithm. Uniaxial shortening $\left(e_{z}\right)$ can be computed from $R_{f}$ using the expression $e_{z}=\left(1 / R_{f}\right)-1$; see Behrmann and Kopf (1993). is opaque material that may be mobilized and redeposited during sediment diagenesis. Under the simplifying assumption that all opaque particles found in thin sections are of detrital origin, we did not take into account any kind of inter-formational transfer. Greigite, which is derived from pyrite in a post-formational, diagenetic reaction, is not primarily a detrital sediment component (see Housen and Musgrave, this volume; Housen and Sato, this volume). In our analysis, greigite is presumed to have formed in a "fixed" position (at initial location) from oxidized framboidal pyrite. Therefore, the initial distribution of detrital pyrite is reflected by greigite. If pyrite was not of detrital origin, its non-random initial distribution would lead to poor-quality results. As an analogy, movements caused by diagenesis would be reflected in non-systematic marker distributions so that resulting poor-quality plots can be precluded. Third, using glaucony as marker particles includes some uncertainties. The term "glaucony" encompasses chlorites, the chamosite-berthierine series, and smectites and micas with partial substitution of ferrous and ferric iron (e.g., Odin, 1985). For all of these minerals, both authigenic and detrital varieties may be present. Our petrographic studies revealed different types of occurrence of glaucony. Detrital pellets of hard, mature glaucony are overgrown by softer grain coatings and incipient alteration to pyrite (see also Westbrook, Carson, Musgrave, et al., 1994). Only dark green, mature glaucony pellets that apparently are detrital in origin were counted for Fry and PODI strain analyses.

\section{Chemical Compositions}

$\mathrm{X}$-ray fluorescence analyses, $\mathrm{x}$-ray diffraction analyses, and electron microprobe analyses were made to determine the chemical compositions of carbonate-bearing sediments and concretions from Sites $889,890,891$, and 892 . X-ray fluorescence spectrometry and X-ray diffraction analyses supplied data from 21 samples taken at all sites cored on Leg 146, except for the reference site off Vancouver Island (Site 888). All samples studied were carbonate concretions with minor amounts of detrital quartz and feldspar. Results of XRF analyses are listed in Tables 2, 3. Additional XRD analyses and electron microprobe analyses further detail the mineralogical composition of the carbonate concretions (Tables 4, 5).

If only carbonate phases are considered, the typical displacement of the calcite- $\left(\mathrm{d}_{104}\right)$-peak is found for almost all concretions analyzed by XRD, and the shift is used to estimate contents in $\mathrm{MgCO}_{3}$ (Goldsmith et al., 1961). Magnesian calcites vary in composition from $7-$ 22 mole $\% \mathrm{MgCO}_{3}$, reflecting substantially higher contents than common deep-water magnesian calcites. The presence of 2.89 - $\AA$ peaks in almost all of the concretions indicates significant amounts of dolomite. Ankerite with $\mathrm{Fe}$ (II), $\mathrm{Mg}$, or $\mathrm{Mn}$ as substitutes reflects the influence by hydrothermal fluids (Reeder and Dollase, 1989), but was convincingly found only in Sample 146-891B-11X-2, 2-6 cm. Because prominent peaks for rhodochrosite, magnesite, and witherite were absent in all XRD patterns (Table 4), the XRF-values for $\mathrm{CaO}$, $\mathrm{MgO}$, and $\mathrm{Fe}_{2} \mathrm{O}_{3}$ together with $\mathrm{CO}_{2}$ were assumed to derive chiefly from carbonates. Thus, total $\mathrm{CO}_{2}$ is partitioned in $\mathrm{CaO}, \mathrm{MgO}$, and $\mathrm{Fe}_{2} \mathrm{O}_{3}$ because of their respective compositions. After a stoichiometric transformation to carbonate and normalization to 100 percent, little or no $\mathrm{CO}_{2}$ remains. Nearly all specimens showed a balance of those oxides and $\mathrm{CO}_{2}$ so we conclude that only minor quantities of any other $\mathrm{Ca}$ - and $\mathrm{Mg}$-rich minerals are present. Small amounts of $\mathrm{CaO}, \mathrm{MgO}$, and $\mathrm{Fe}_{2} \mathrm{O}_{3}$ that remain in few samples, according to our petrographic studies (see above), are believed to be contained mainly in feldspars (in case of $\mathrm{Ca}$ and $\mathrm{Fe}$ ) and phyllosilicates ( $\mathrm{Fe}, \mathrm{Mg}$ ) respectively. For the estimation of the $\mathrm{Ca} / \mathrm{Mg}$ ratio, $\mathrm{FeCO}_{3}$ was not considered because of its low abundance (see discussion below). Additionally, none of the XRD patterns revealed any characteristic $2.80-\AA$ and $1.73-\AA ̊$ reflections for siderite. Therefore, our assumption should be tolerable, even if a distinct portion of $\mathrm{Fe}$ (II) may be present 
A

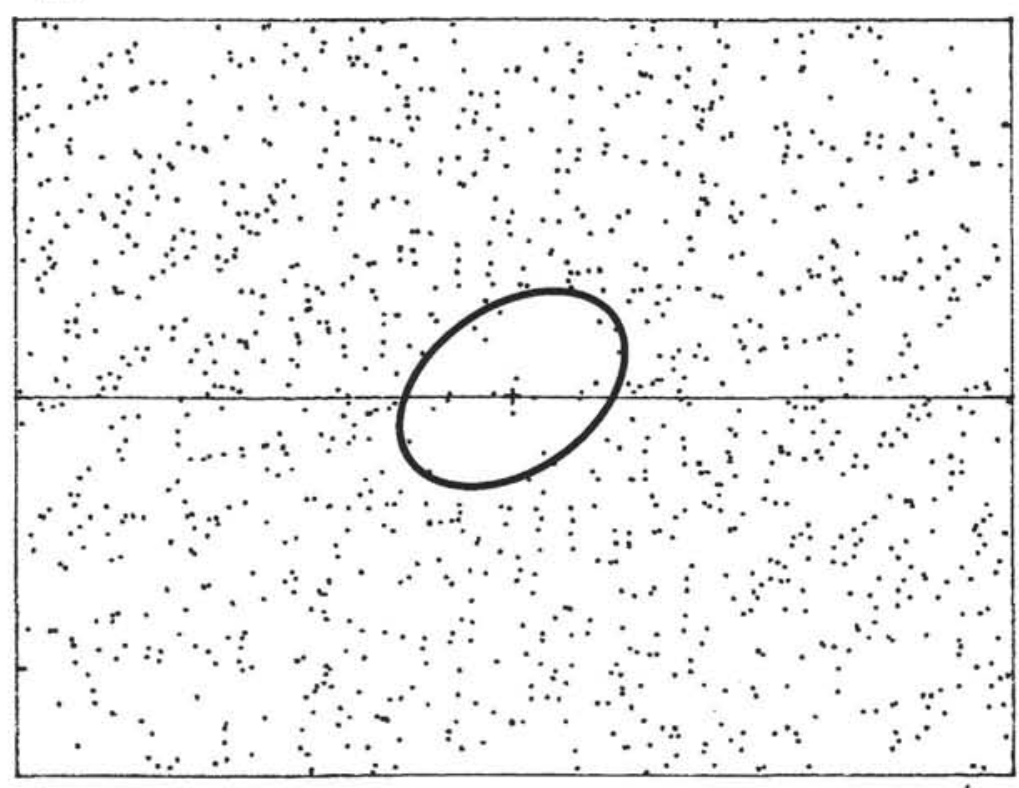

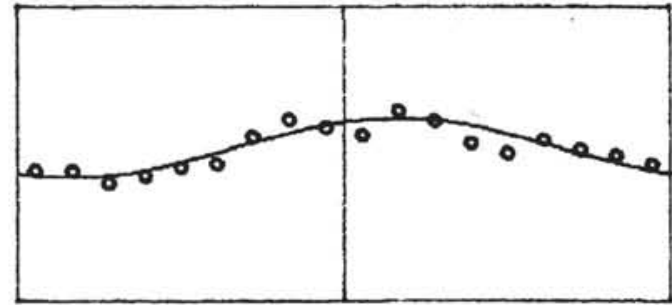

PODI: Af versug Theta

B

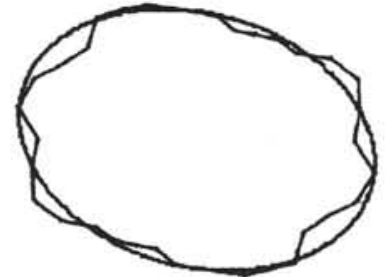

Figure 4. Results of Fry and PODI strain determinations on Sample 146-892A-15X-1, 2-3 cm. Marker particles are detrital glaucony in thin section. A. Visual estimation using the Fry technique. Marked area in the center of the diagram is the visually inferred shape of the strain ellipse. Axial ratio $\left(R_{f}\right)$ is 1.59 . B. Result of the PODI strain calculation on the same data set with diagram showing the least squares fitted sine function. $R_{f}$ is 1.49.

Table 2. XRF data for major oxides (in wt \%) and Sr (in ppm), corrected against calibration curve.

\begin{tabular}{|c|c|c|c|c|c|c|c|c|c|c|c|c|c|c|c|}
\hline $\begin{array}{l}\text { Core, section, } \\
\text { interval }(\mathrm{cm})\end{array}$ & $\mathrm{SiO}_{2}$ & $\mathrm{TiO}_{2}$ & $\mathrm{Al}_{2} \mathrm{O}_{3}$ & $\mathrm{Fe}_{2} \mathrm{O}_{3}$ & $\mathrm{MnO}$ & $\mathrm{MgO}$ & $\mathrm{CaO}$ & $\mathrm{Na}_{2} \mathrm{O}$ & $\mathrm{K}_{2} \mathrm{O}$ & $\mathrm{P}_{2} \mathrm{O}_{5}$ & $\mathrm{CO}_{2}$ & $\mathrm{H}_{2} \mathrm{O}$ & Total & $\mathrm{C}_{\text {total }}$ & $\mathrm{Sr}$ \\
\hline \multicolumn{16}{|l|}{ 146-889B- } \\
\hline $3 R-1,0-4$ & 11.87 & 0.22 & 3.46 & 2.67 & 0.14 & 12.29 & 27.50 & 0.41 & 0.42 & 1.80 & 32.98 & 2.40 & 96.15 & 9.00 & 367 \\
\hline $6 \mathrm{R}-1,8-16$ & 48.65 & 0.81 & 13.27 & 4.53 & 0.05 & 2.82 & 3.87 & 2.67 & 1.84 & 0.21 & 12.46 & 6.90 & 98.08 & 3.40 & 295 \\
\hline $7 R-4,78-79$ & 17.80 & 0.30 & 6.26 & 6.70 & 0.28 & 3.22 & 33.07 & 1.12 & 0.80 & 0.38 & 27.11 & 2.20 & 99.24 & 7.40 & 446 \\
\hline $8 \mathrm{R}-1,4-6$ & 27.20 & 0.45 & 7.10 & 3.76 & 0.20 & 5.38 & 22.46 & 1.18 & 1.04 & 0.38 & 24.18 & 4.20 & 97.55 & 6.60 & 596 \\
\hline $16 \mathrm{R}-1,1-3$ & 15.00 & 0.30 & 4.86 & 3.03 & 0.20 & 6.02 & 32.65 & 0.60 & 0.58 & 0.52 & 29.68 & 4.20 & 97.65 & 8.10 & 964 \\
\hline $18 \mathrm{R}-1,12-15$ & 11.87 & 0.25 & 3.93 & 3.31 & 0.08 & 12.82 & 27.08 & 0.41 & 0.54 & 0.29 & 34.81 & 2.50 & 97.88 & 9.50 & 422 \\
\hline $19 \mathrm{R}-1,2-5$ & 17.63 & 0.31 & 5.51 & 3.09 & 0.22 & 3.85 & 35.81 & 0.80 & 0.63 & 0.40 & 27.04 & 2.23 & 97.53 & 7.38 & 813 \\
\hline 20R-CC, 5-9 & 18.05 & 0.29 & 5.33 & 2.88 & 0.08 & 9.82 & 24.69 & 0.84 & 0.70 & 0.41 & 28.21 & 2,70 & 94.00 & 7.70 & 953 \\
\hline $21 \mathrm{R}-1,64-68$ & 18.31 & 0.31 & 5.89 & 2.41 & 0.04 & 5.02 & 33.60 & 0.77 & 0.75 & 0.28 & 30.78 & 3.30 & 101.45 & 8.40 & 720 \\
\hline \multicolumn{16}{|l|}{ 146-890B- } \\
\hline $3 \mathrm{H}-7,0-4$ & 27.12 & 0.43 & 7.48 & 2.89 & 0.07 & 5.61 & 21.58 & 1.26 & 0.91 & 0.24 & 21.98 & 3.10 & 92.67 & 6.00 & 800 \\
\hline \multicolumn{16}{|l|}{ 146-891B- } \\
\hline \multicolumn{16}{|l|}{$146-892 \mathrm{~A}-$} \\
\hline $3 \mathrm{X}-2,99-101$ & 9.83 & 0.16 & 2.99 & 1.52 & 0.03 & 5.37 & 43.00 & 0.41 & 0.39 & 0.15 & 35.18 & 1.80 & 100.82 & 9.60 & 1696 \\
\hline $4 X-1,4-5$ & 17.29 & 0.27 & 5.05 & 2.24 & 0.03 & 6.55 & 34.34 & 0.71 & 0.73 & 0.27 & 28.95 & 2.20 & 98.62 & 7.90 & 715 \\
\hline $6 \mathrm{X}-\mathrm{CC}, 18-21$ & 15.00 & 0.19 & 3.27 & 2.60 & 0.04 & 9.79 & 32.98 & 0.46 & 0.37 & 0.15 & 33.71 & 1.80 & 100.36 & 9.20 & 504 \\
\hline $7 \mathrm{X}-3,150-152$ & 16.02 & 0.24 & 4.39 & 3.47 & 0.02 & 4.72 & 35.64 & 0.62 & 0.75 & 0.37 & 31.14 & 3.70 & 101.10 & 8.50 & 792 \\
\hline $15 X-1,2-3$ & 17.12 & 0.28 & 4.86 & 2.25 & 0.02 & 8.38 & 30.36 & 0.69 & 0.72 & 0.24 & 31.14 & 3.70 & 99.77 & 8.50 & 608 \\
\hline $21 X-1,0-24$ & 7.88 & 0.13 & 1.78 & 2.85 & 0.09 & 15.81 & 28.31 & 0.25 & 0.24 & 0.27 & 37.74 & 2.50 & 97.85 & 10.30 & 896 \\
\hline \multicolumn{16}{|l|}{ 146-892D- } \\
\hline $4 X-1,0-2$ & 20.68 & 0.32 & 6.07 & 2.65 & 0.03 & 5.20 & 32.15 & 0.96 & 0.84 & 0.13 & 26.38 & 3.60 & 99.02 & 7.20 & 622 \\
\hline $6 X-3,13-15$ & 13.31 & 0.19 & 3.27 & 4.15 & 0.01 & 5.83 & 36.11 & 0.50 & 0.53 & 0.17 & 32.98 & 3.20 & 100.27 & 9.00 & 687 \\
\hline $6 \mathrm{X}-3,107-112$ & 15.34 & 0.21 & 3.64 & 3.28 & 0.02 & 5.96 & 36.41 & 0.64 & 0.51 & 0.12 & 34.08 & 3.60 & 103.81 & 9.30 & 688 \\
\hline \multicolumn{16}{|l|}{$146-892 \mathrm{E}-$} \\
\hline IX-2, 74-76 & 13.39 & 0.23 & 4.30 & 1.93 & 0.02 & 6.59 & 37.53 & 0.61 & 0.60 & 0.20 & 32.24 & 2.40 & 100.04 & 8.80 & 711 \\
\hline
\end{tabular}

in the lattice of the complex carbonates. Finally, on the basis of weight percentages for $\mathrm{CaCO}_{3}$ and $\mathrm{MgCO}_{3}$, the $\mathrm{Ca} / \mathrm{Mg}$ ratio is calculated. Results are listed in Table 3.

As illustrated by high contents of $\mathrm{CO}_{2}$ (Tables 2,3 ), most of the concretions contain a large proportion of carbonates, represented by major amounts of $\mathrm{CaO}, \mathrm{MgO}$, and $\mathrm{CO}_{2}$ in nearly all samples. Carbonate concretions with high content of detrital quartz or feldspar are rare (e.g., Sample 146-889B-6R-1, 8-16 cm, or 146-889B-11X-2, 2-6 $\mathrm{cm}$; Pl. 1, Fig. 3). High $\mathrm{Al}_{2} \mathrm{O}_{3}$ content probably reflects the abundance of feldspar and clay minerals. The distribution and the appearance of $\mathrm{Fe}_{2} \mathrm{O}_{3}$ as a component of different minerals cannot be estimated accurately because of the large number of possible minerals containing $\mathrm{Fe}$ in their lattices. Assuming conservatively that all iron is precipitated as $\mathrm{FeCO}_{3}$, those values rarely exceed $4 \mathrm{wt} \%$, so that our estimated content of $\mathrm{CaCO}_{3}$ and $\mathrm{MgCO}_{3}$ is inaccurate by no more than 2 $w t \%$. On the other hand, none of our XRD patterns showed a siderite 
Table 3. XRF data standardized for $\mathrm{CaCO}_{3}$ and $\mathrm{MgCO}_{3}$ to determine the $\mathrm{Ca} / \mathrm{Mg}$ ratio.

\begin{tabular}{|c|c|c|c|c|c|c|c|c|c|}
\hline $\begin{array}{l}\text { Core, section, } \\
\text { interval }(\mathrm{cm})\end{array}$ & $\begin{array}{l}\text { Depth } \\
\text { (mbsf) }\end{array}$ & $\begin{array}{c}\mathrm{CaO} \\
(\mathrm{wt} \%)\end{array}$ & $\begin{array}{c}\mathrm{MgO} \\
(\mathrm{wt} \%)\end{array}$ & $\begin{array}{l}\mathrm{CO}_{2} \\
\text { (wt\%) }\end{array}$ & $\begin{array}{l}\mathrm{CaCO}_{3} \\
\text { (wt\%) }\end{array}$ & $\begin{array}{l}\mathrm{MgCO}_{3} \\
(\mathrm{wt} \%)\end{array}$ & $\begin{array}{c}\text { Carbonate } \\
\left(w t^{2} \%\right)\end{array}$ & $\begin{array}{r}\mathrm{CaCO}_{3} \\
(\mathrm{~mol} \%)\end{array}$ & $\begin{array}{l}\mathrm{MgCO}_{3} \\
(\mathrm{~mol} \%)\end{array}$ \\
\hline \multicolumn{10}{|l|}{ 146-889B- } \\
\hline $3 \mathrm{R}-1,0-4$ & 216 & 27.51 & 12.29 & 32.98 & 46.16 & 24.16 & 70.32 & 62 & 38 \\
\hline $6 \mathrm{R}-1,8-16$ & 244 & 3.87 & 2.82 & 12.46 & 6.92 & 5.89 & 12.81 & 50 & 50 \\
\hline $7 R-4,78-79$ & 258 & 33.07 & 3.22 & 27.11 & 54.29 & 6.22 & 60.51 & 88 & 12 \\
\hline $8 \mathrm{R}-1,4-6$ & 262 & 22.46 & 5.38 & 24.18 & 41.37 & 11.44 & 52.81 & 75 & 25 \\
\hline $16 \mathrm{R}-1,1-3$ & 333 & 32.65 & 6.02 & 29.68 & 53.65 & 11.63 & 65.28 & 80 & 20 \\
\hline $18 \mathrm{R}-1,12-15$ & 351 & 27.08 & 12.82 & 34.81 & 47.78 & 26.29 & 74.07 & 60 & 40 \\
\hline 19R-1, 2-5 & 360 & 35.81 & 3.85 & 27.04 & 53.36 & 6.86 & 60.22 & 87 & 13 \\
\hline 20R-CC, 5-9 & 369 & 24.69 & 9.82 & 28.21 & 41.23 & 19.21 & 60.44 & 64 & 36 \\
\hline $21 R-1,64-68$ & 378 & 33.60 & 5.02 & 30.78 & 57.98 & 10.11 & 68.09 & 83 & 17 \\
\hline \multicolumn{10}{|l|}{ 146-890B- } \\
\hline \multicolumn{10}{|l|}{ 146-891B- } \\
\hline $11 X-2,2-6$ & 92 & 18.91 & 2.25 & 16.49 & 32.19 & 4.47 & 36.66 & 86 & 14 \\
\hline \multicolumn{10}{|l|}{ 146-891A- } \\
\hline $3 \mathrm{X}-2,99-101$ & 21 & 43.00 & 5.37 & 35.18 & 68.05 & 10.06 & 78.11 & 85 & 15 \\
\hline $4 X-1,4-5$ & 28 & 34.34 & 6.55 & 28.95 & 51.80 & 11.78 & 63.58 & 79 & 21 \\
\hline $6 \mathrm{X}-\mathrm{CC}, 18-21$ & 46 & 32.98 & 9.79 & 33.71 & 54.14 & 18.89 & 73.03 & 71 & 29 \\
\hline $7 X-3,150-152$ & 53 & 35.64 & 4.72 & 31.14 & 59.80 & 9.28 & 69.08 & 84 & 16 \\
\hline $15 X-1,2-3$ & 116 & 30.36 & 8.38 & 31.14 & 51.13 & 16.52 & 67.65 & 72 & 28 \\
\hline $21 X-1,0-24$ & 173 & 28.31 & 15.81 & 37.74 & 48.25 & 31.47 & 79.72 & 56 & 44 \\
\hline \multicolumn{10}{|l|}{$146-892 \mathrm{D}-$} \\
\hline $4 X-1,0-2$ & 27 & 32.15 & 5.20 & 26.38 & 48.81 & 9.41 & 58.22 & 81 & 19 \\
\hline $6 X-3,13-15$ & 50 & 36.11 & 5.83 & 32.98 & 61.24 & 11.56 & 72.80 & 82 & 18 \\
\hline $6 X-3,107-112$ & 50 & 36.41 & 5.96 & 34.08 & 63.17 & 12.04 & 75.21 & 82 & 18 \\
\hline \multicolumn{10}{|l|}{$146-892 \mathrm{E}-$} \\
\hline $1 X-2,74-76$ & 1 & 37.53 & 6.59 & 32.24 & 58.33 & 12.95 & 71.28 & 80 & 20 \\
\hline
\end{tabular}

Table 4. XRD determination data from 24 carbonate concretions.

\begin{tabular}{|c|c|c|c|c|c|c|c|c|c|c|}
\hline $\begin{array}{l}\text { Core, section, interval }(\mathrm{cm}) \text {, } \\
\text { measure point }\end{array}$ & $\begin{array}{l}\mathrm{MgCO}_{3} \\
(\mathrm{wt} \%)\end{array}$ & $\begin{array}{l}\mathrm{CaCO}_{3} \\
\text { (wt } \%)\end{array}$ & $\begin{array}{l}\mathrm{MnCO}_{3} \\
(\mathrm{wt} \%)\end{array}$ & $\begin{array}{l}\mathrm{FeCO}_{3} \\
(\mathrm{wt} \%)\end{array}$ & $\begin{array}{l}\mathrm{CuCO}_{3} \\
\text { (wt } \%)\end{array}$ & $\begin{array}{l}\mathrm{ZnCO}_{3} \\
(\mathrm{wt} \%)\end{array}$ & $\begin{array}{l}\mathrm{SrCO}_{3} \\
(\mathrm{wt} \%)\end{array}$ & $\begin{array}{l}\mathrm{BaCO}_{3} \\
\text { (wt } \% \text { ) }\end{array}$ & $\begin{array}{l}\mathrm{PbCO}_{3} \\
\text { (wt\%) }\end{array}$ & $\begin{array}{l}\text { Total } \\
\text { (wt \%) }\end{array}$ \\
\hline \multicolumn{11}{|l|}{$\begin{array}{l}146-892 \mathrm{~A}- \\
20 \mathrm{X}-1,13-15\end{array}$} \\
\hline 1 & 26.67 & 66.81 & 0.05 & 3.33 & 0.10 & 0.23 & 0.20 & 0.08 & 0.00 & 97.47 \\
\hline 2 & 31.88 & 42.04 & 0.18 & 26.14 & 0.00 & 0.00 & 0.00 & 0.28 & 0.00 & 100.53 \\
\hline \multicolumn{11}{|l|}{ Profile through a vein filling } \\
\hline $3 / 1$ & 37.47 & 54.41 & 0.33 & 4.43 & 0.00 & 0.00 & 0.23 & 0.41 & 0.00 & 97.27 \\
\hline $3 / 2$ & 36.92 & 52.80 & 0.06 & 5.10 & 0.00 & 0.11 & 0.05 & 0.44 & 0.05 & 95.50 \\
\hline $3 / 3$ & 35.79 & 57.35 & 0.19 & 4.18 & 0.15 & 0.00 & 0.05 & 0.46 & 0.00 & 98.17 \\
\hline $3 / 4$ & 36.39 & 56.58 & 0.04 & 4.87 & 0.00 & 0.25 & 0.05 & 0.39 & 0.00 & 98.56 \\
\hline $3 / 5$ & 36.65 & 54.95 & 0.00 & 4.96 & 0.19 & 0.00 & 0.06 & 0.29 & 0.00 & 97.10 \\
\hline $3 / 6$ & 34.98 & 55.44 & 0.08 & 4.99 & 0.19 & 0.00 & 0.11 & 0.36 & 0.05 & 96.15 \\
\hline $3 / 7$ & 36.59 & 55.76 & 0.24 & 3.42 & 0.01 & 0.15 & 0.17 & 0.33 & 0.15 & 96.66 \\
\hline $3 / 8$ & 38.32 & 52.97 & 0.00 & 5.02 & 0.00 & 0.00 & 0.05 & 0.35 & 0.00 & 96.70 \\
\hline 4 & 38.12 & 52.00 & 0.17 & 5.12 & 0.03 & 0.00 & 0.00 & 0.37 & 0.00 & 95.80 \\
\hline 5 & 38.62 & 53.77 & 0.00 & 3.86 & 0.06 & 0.11 & 0.07 & 0.47 & 0.11 & 97.06 \\
\hline 6 & 35.89 & 54.09 & 0.00 & 4.48 & 0.00 & 0.00 & 0.00 & 0.32 & 0.00 & 94.78 \\
\hline \multicolumn{11}{|l|}{$\begin{array}{l}146-892 \mathrm{D}- \\
10 \mathrm{X}-5,91-93\end{array}$} \\
\hline 1 & 1.20 & 90.56 & 0.75 & 2.23 & 0.06 & 0.02 & 0.05 & 0.02 & 0.04 & 94.93 \\
\hline 2 & 1.33 & 91.59 & 0.54 & 2.51 & 0.01 & 0.09 & 0.07 & 0.03 & 0.10 & 96.27 \\
\hline 3 & 1.19 & 92.47 & 0.79 & 2.16 & 0.07 & 0.01 & 0.12 & 0.04 & 0.17 & 97.01 \\
\hline 4 & 1.13 & 95.20 & 0.46 & 2.99 & 0.06 & 0.02 & 0.10 & 0.00 & 0.11 & 100.08 \\
\hline 5 & 0.87 & 91.16 & 0.34 & 2.23 & 0.00 & 0.06 & 0.00 & 0.01 & 0.06 & 94.76 \\
\hline \multicolumn{11}{|l|}{$\begin{array}{l}\text { 146-892D- } \\
8 \mathrm{X}-\mathrm{CC}, 20-22\end{array}$} \\
\hline 1 & 0.14 & 93.76 & 2.13 & 0.12 & 0.03 & 0.04 & 0.13 & 0.03 & 0.02 & 96.40 \\
\hline 2 & 0.01 & 93.42 & 1.88 & 0.07 & 0.01 & 0.01 & 0.22 & 0.03 & 0.03 & 95.69 \\
\hline 3 & 0.02 & 96.09 & 0.56 & 0.16 & 0.00 & 0.06 & 0.13 & 0.03 & 0.07 & 97.12 \\
\hline 4 & 0.24 & 93.20 & 2.21 & 0.07 & 0.03 & 0.07 & 0.29 & 0.03 & 0.05 & 96.19 \\
\hline 5 & 0.06 & 95.71 & 0.27 & 0.03 & 0.05 & 0.05 & 0.11 & 0.02 & 0.07 & 96.36 \\
\hline 6 & 0.26 & 92.43 & 2.59 & 0.03 & 0.07 & 0.06 & 0.26 & 0.00 & 0.10 & 95.79 \\
\hline \\
\hline${ }_{1}^{8 X-C C}, 16-21$ & 0.53 & 91.62 & 1.88 & 0.99 & 0.04 & 0.32 & 0.27 & 0.00 & & \\
\hline 2 & 0.62 & 91.67 & 1.72 & 0.89 & 0.02 & 0.06 & $\begin{array}{l}0.27 \\
0.42\end{array}$ & 0.00 & 0.00 & 95.39 \\
\hline 3 & 0.02 & 93.64 & 1.11 & 0.05 & 0.04 & 0.09 & 0.14 & 0.00 & 0.04 & 95.12 \\
\hline 5 & 0.06 & 93.21 & 1.85 & 0.19 & 0.00 & 0.06 & 0.13 & 0.00 & 0.03 & 95.54 \\
\hline 6 & 0.04 & 93.75 & 1.72 & 0.04 & 0.01 & 0.02 & 0.10 & 0.01 & 0.07 & 95.76 \\
\hline 7 & 0.12 & 94.01 & 0.53 & 0.07 & 0.21 & 0.11 & 0.07 & 0.01 & 0.01 & 95.12 \\
\hline
\end{tabular}

Note: Results of electron microprobe analyses: each row reflects the calculated mean average values derived from up to 16 sub-point measurements at a particular location. See text. 
Table 5. Results of electron microprobe analyses.

\begin{tabular}{|c|c|c|c|}
\hline $\begin{array}{l}\text { Core, section, } \\
\text { interval }(\mathrm{cm})\end{array}$ & $\begin{array}{l}\text { Peak calcite } \mathrm{d}_{\text {(104) }} \\
\text { position }\end{array}$ & $\begin{array}{c}\mathrm{MgCO}_{3} \text { in } \\
\text { magnesian calcite } \\
\text { calculated } \\
\text { (mol\%) }\end{array}$ & $\begin{array}{l}\text { Dolomite } \\
\text { identified }\end{array}$ \\
\hline \multicolumn{4}{|l|}{ 146-889B- } \\
\hline $\begin{array}{l}3 \mathrm{R}-1,0-4 \\
7 \mathrm{R}-4,78-79\end{array}$ & $3 . \overline{0091}$ & $\overline{8}$ & $\begin{array}{l}\text { High peak } \\
\text { No }\end{array}$ \\
\hline $8 \mathrm{R}-1.4-6$ & 3.0141 & 7 & Yes \\
\hline $16 \mathrm{R}-1,1-3$ & 3.0031 & 12 & High peak \\
\hline $18 \mathrm{R}-1,12-15$ & 2.9855 & 18 & \\
\hline $19 \mathrm{R}-1,2-5$ & 3.0112 & 8 & No \\
\hline 20R-CC, $5-9$ & 2.9912 & 15 & High peak \\
\hline $21 \mathrm{R}-1,64-68$ & - & - & \\
\hline $\begin{array}{l}146-890 \mathrm{~B}- \\
3 \mathrm{H}-7,24-30\end{array}$ & 2.9779 & 13 & No \\
\hline \multicolumn{4}{|l|}{$\begin{array}{l}146-891 \mathrm{~B}- \\
1 \mathrm{X}-2,2-6\end{array}$} \\
\hline IIX-2, 2-6 & 2.9901 & 16 & Yes \\
\hline \multicolumn{4}{|l|}{$146-892 \mathrm{~A}-$} \\
\hline $3 X-2,99-101$ & 2.9771 & 22 & No \\
\hline $4 X-1,4-5$ & 3.0103 & 8 & No \\
\hline $6 \mathrm{X}-\mathrm{CC}, 18-21$ & 3.0004 & 13 & Yes \\
\hline $7 X-3,150-152$ & 2.9854 & 17 & \\
\hline $15 X-1,2-3$ & 3.0043 & 12 & High peak \\
\hline $21 X-1,0-24$ & 2.9844 & 17 & Yes \\
\hline \multicolumn{4}{|l|}{ 146-892D- } \\
\hline $4 \mathrm{X}-1,0-2$ & 3.0031 & 11 & Yes \\
\hline $6 \mathrm{X}-3,103-105$ & 3.0024 & 12 & Yes \\
\hline \multicolumn{4}{|l|}{ 146-892E- } \\
\hline
\end{tabular}

Notes: Each row reflects the calculated mean average values derived from up to 16 subpoint measurements at a particular location. Data are in wt\%. See text.

peak, so that elevated contents in $\mathrm{FeCO}_{3}$ indicate the presence of complex carbonates. $\mathrm{MnO}$ values are less than $0.5 \mathrm{wt} \%$ while $\mathrm{Sr}$ values do not exceed $1000 \mathrm{ppm}$. At these abundances, $\mathrm{Mn}$ and $\mathrm{Sr}$ can be hosted in lattices of complex carbonates without precipitation of rhodochrosite or strontianite.

To sum, results of combined XRF and XRD determinations show elevated $\mathrm{MgCO}_{3}$ content of calcite in most of the specimens. If we accept a $5 \mathrm{wt} \% \mathrm{MgCO}_{3}$ as the lower limit for high-Mg calcite, about $90 \%$ of the concretions analyzed are composed of high- $\mathrm{Mg}$ calcite, ranging between $8-22$ mole $\% \mathrm{MgCO}_{3}$. Carbonate with near-dolomitic composition was found in $10 \%$ of our samples (e.g., Samples 146889B-6R-1, 8-16 cm, and 146-891A-21X-1, 0-24 cm; Table 3).

Electron microprobe analyses were made to examine samples from Site 892 only, both on lithified sediments with carbonate cements and vein fills and on carbonate concretions. Determination of relative proportions of different carbonate minerals and possible zonation patterns of concretions and vein cements were the main reasons for undertaking the electron microprobe study. Furthermore, representative carbonate concretions should be compared to dark gray, brecciated concretions and accompanying sediments in the vicinity of the prominent fault zone at 62-67 mbsf (Site 892D; cf. Westbrook, Carson, Musgrave, et al., 1994). Measurements were made focusing exclusively on single carbonate minerals, so that impurities and uncertainties concerning other minerals would be negligible. Results are listed in Table 4. Both concretions and cemented veins were examined in the step scan mode. Between specimens there are distinct compositional differences (Table 4). Sample 146-892A$20 \mathrm{X}-1,13-15 \mathrm{~cm}$, represents a characteristic carbonate concretion because of its texture, degree of cementation, and visually estimated composition, and it is believed to be characteristic for most of the samples analyzed by XRF and XRD (see Tables 2-4). Both the concretionary cement and the healed veins were analyzed (Figs. 5 and 6). The micritic matrix consists of $40-70 \mathrm{wt} \%$ of $\mathrm{CaCO}_{3}$ and $25-40 \mathrm{wt} \%$ of $\mathrm{MgCO}_{3} . \mathrm{FeCO}_{3}$ content ranges between $3 \mathrm{wt} \%$ and $5 \mathrm{wt} \%$ except for one analysis spot where more than $25 \mathrm{wt} \%$ was found because the electron beam was focused on a tiny iron-rich inclusion (cf. Table 4).
The microvein cement is not chemically zoned and has a high-Mg calcite composition that is similar to the matrix (Table 5). In comparison to that, three samples from within or nearby the fault zone (6267 mbsf, see Westbrook, Carson, Musgrave, et al., 1994) were measured. Sample $146-892 \mathrm{D}-8 \mathrm{X}-\mathrm{CC}, 32-37 \mathrm{~cm}$ is a dark gray, very indurated carbonate concretion that includes small sedimentary lithics. It is composed of almost pure calcite with significant amounts of $\mathrm{MnCO}_{3}$ (up to $2.59 \mathrm{wt} \%$ ). Sample 146-892D-8X-CC, 16-21 cm, consists of brecciated sedimentary lithic fragments in a muddy matrix. The lithic fragments contain fractures filled by twinned calcite (cf. Pl. 1, Fig. 1). Vein cement shows very high calcite contents (>90 wt\%) and up to 1.88 wt \% of $\mathrm{MnCO}_{3}$. Significant content of $\mathrm{SrCO}_{3}$ was found (around 0.1-0.4 wt\%, cf. Table 4). Sample 146-892D-10X-5, $91-93 \mathrm{~cm}$ represents a cemented silty clay. Data indicate that the fine-grained, dispersed carbonate is almost pure calcite (>90 wt \%), with small admixtures of $\mathrm{MgCO}_{3}(\sim 1.2 \mathrm{wt} \%), \mathrm{MnCO}_{3}(\sim 1.5 \mathrm{wt} \%)$, and $\mathrm{FeCO}_{3}(2-3 \mathrm{wt} \%$ ) (cf. Table 4$)$. Results reflect a substantially different carbonate composition in the major fault zone compared to common authigenic carbonates (Sample 146-892A-20X-1, 13-15 $\mathrm{cm})$. In contrast to almost pure calcite as the dominant carbonate phase in the vicinity of the fault zone, combined XRF and XRD data imply that most of the remaining concretions consist of complex carbonates or high- $\mathrm{Mg}$ calcite. An enrichment in $\mathrm{MnCO}_{3}$ and $\mathrm{FeCO}_{3}$ of all samples taken from the fault zone suggests precipitation as complex carbonates, too.

\section{Oxygen and Carbon Isotopic Compositions}

Stable isotopes of carbon and oxygen were determined for 28 specimens of concretionary cements (24 samples, cf. Table 5) and
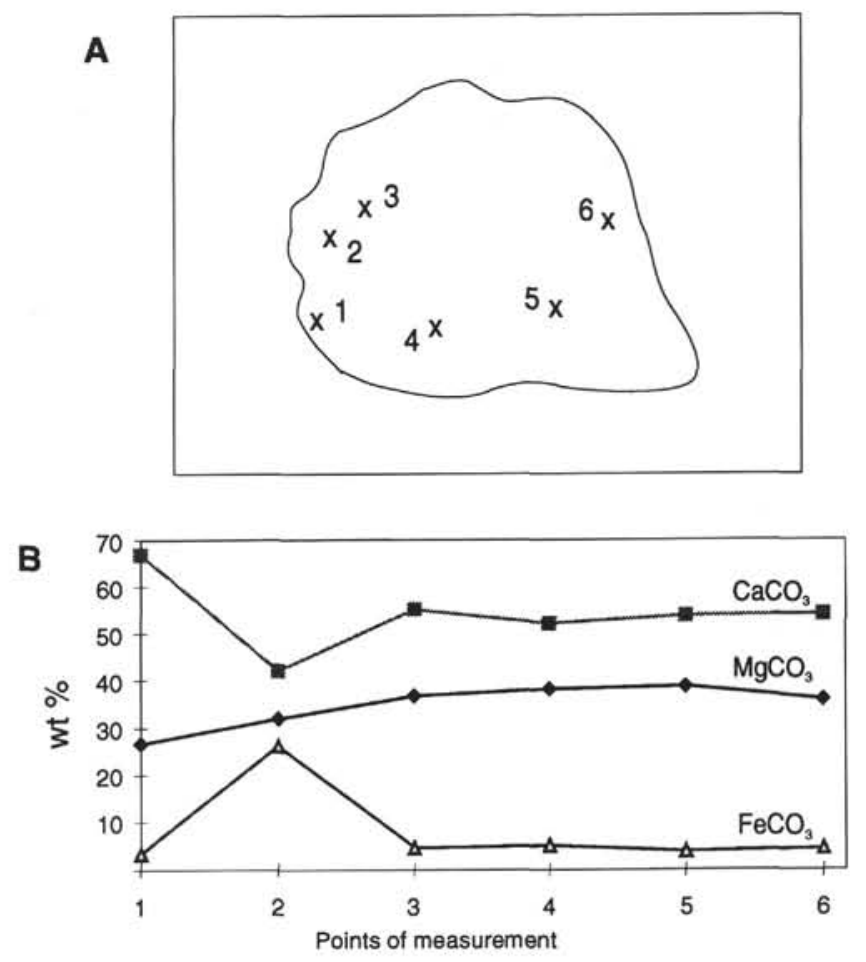

Figure 5. Sample 146-892A-20X-1, 13-15 cm. A. Sketch of a carbonate concretion about $40 \mathrm{~mm}$ in diameter. An X marks each location where electron microprobe analysis was made. B. Diagram showing the content of $\mathrm{CaCO}_{3}$, $\mathrm{MgCO}_{3}$, and $\mathrm{FeCO}_{3}$ (wt \%) at the different locations across the concretion. Data presented in Table 4 show significant amounts of $\mathrm{FeCO}_{3}$ and distinct amounts of $\mathrm{MnCO}_{3}$ displaying complex carbonate associations. See text. 
A

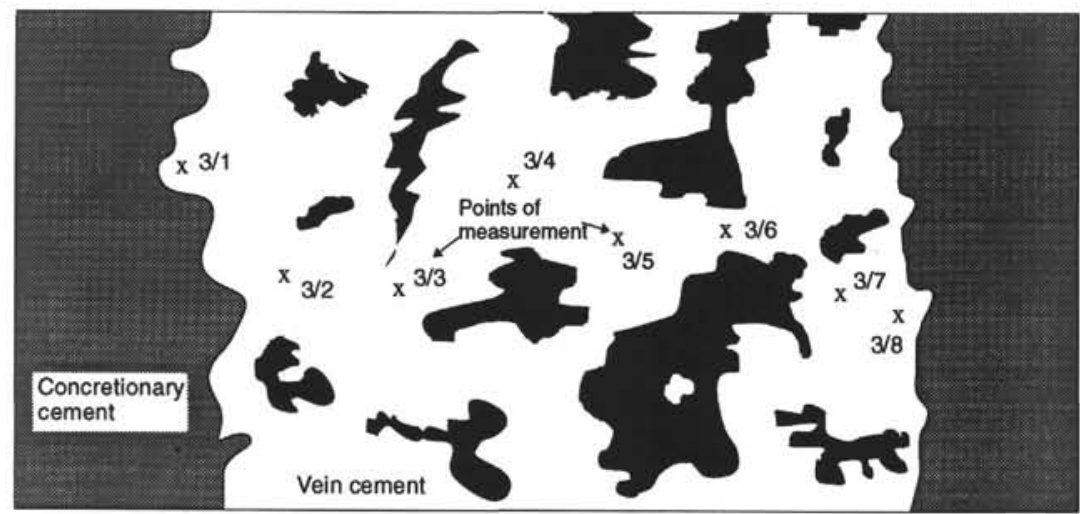

B

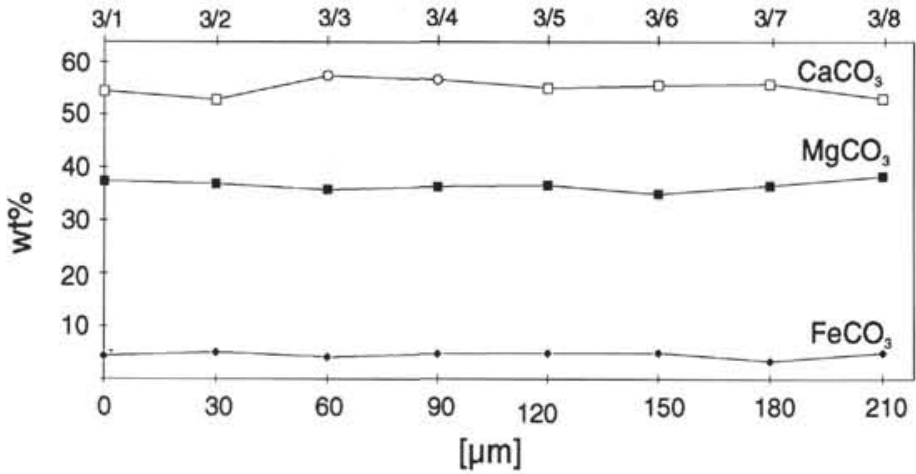

Figure 6. Sample 146-892D-10X-5, 91-93 cm. A. Sketch of a cemented vein filled with carbonate examined via electron microprobe analysis. Measurements were made in step scan mode with a distance of $30 \mu \mathrm{m}$ between each sub-point measured. Black areas are artificial veins caused by preparation. B. Content of $\mathrm{CaCO}_{3}, \mathrm{MgCO}_{3}$, and $\mathrm{FeCO}_{3}$ (wt \%) at the different locations inside the vein. Diameter of the vein is approximately 220 $\mu \mathrm{m}$. As in the surrounding sediment, significant amounts of $\mathrm{FeCO}_{3}$ and $\mathrm{MnCO}_{3}$ (Table 4) display complex carbonate composition of the healed vein. See text. carbonate cemented microveins in sedimentary lithic fragments. ${ }^{13} \mathrm{C} /$ ${ }^{12} \mathrm{C}$ isotope ratios may indicate a biogenic or thermogenic origin of the methane carbon incorporated during carbonate precipitation (see above, and Higgins and Quale, 1970; Reeburgh, 1980; Ritger et al., 1987). ${ }^{18} \mathrm{O} /{ }^{16} \mathrm{O}$ isotope ratios may provide important information pertaining to the temperature and origin of fluids from which diagenetic carbonates are precipitated. Additionally, zonation patterns of carbon and oxygen isotopes in concretions and vein fillings provide insights into changes of the isotopic composition in the pore fluid during the cementation process (Fig. 7). Results of isotopic signatures of 13 selected samples from Sites 889, 891, and 892 are listed in Table 6.

The data can be divided into four groups (Figs. 8 and 9). A first set of samples taken in the vicinity of the prominent fault zone at Site 892 (62-67 mbsf, Fig. 3) shows negative values for both $\delta^{13} \mathrm{C}(-10 \%$ o to $0 \%$ PDB) and $\delta^{18} \mathrm{O}(-11.7 \%$ to $-15.5 \%$ PDB). Lithologies measured were concretionary cements and calcareous matrix of sedimentary lithic fragments with healed microveins (cf. Sample 146-892D$8 \mathrm{X}-\mathrm{CC}, 16-21 \mathrm{~cm}$ as an example; see also Plate 1, Fig.1, and Group A in Table 6). A second group of specimens, mainly taken at Site 889, revealed isotope signatures that are similar to those of modern ocean water (e.g., James and Choquette, 1983; cf. Group B in Table 6). Carbon isotope ratios show a wide range for $\delta^{13} \mathrm{C}$ from $-2 \%$ to $+25 \%$ o $\mathrm{PDB}$, where enrichment in ${ }^{13} \mathrm{C}$ in a few samples may be related to fermentation processes (see discussion below). A third group of samples of carbonate concretions shows depletion in ${ }^{13} \mathrm{C}(-22 \%$ to $-5 \%$ o PDB) and about $0 \%$ to $+5 \%$ for $\delta^{18} \mathrm{O}$ (Figs. 8 and 9 , and also Group $\mathrm{C}$ in Table 6). A last group of data (Group D in Table 6) is from micritic concretions with variable degrees of induration. That material exclusively originates from the Oregon sites and shows markedly stronger depletion in ${ }^{13} \mathrm{C}$ compared with groups $\mathrm{A}-\mathrm{C}$ (Table 6). Samples from Sites 892A, 892D, and 892E not related to the fault zone yield $\delta^{13} \mathrm{C}$ values from $-28 \%$ to $-52 \%$ PDB, indicating a sizeable biogenic contribution to the methane consumed in carbonate precipitation (cf. Rosenfeld and Silverman, 1959). Samples taken at high stratigraphic levels show variations between $+3.5 \%$ and $+5.5 \%$ PDB for $\delta^{18} \mathrm{O}$. Specimens show either no isotopic zonation (e.g., Sample 146-892A-4X-1, 4-5 cm; Table 6) or well-developed zonation patterns (e.g., Sample 146-892D-6X-3,107-112 cm; cf. Fig. 7 and Table $5)$. Isotopically zoned vein cements were not observed.

Changes in the isotopic signatures are evident when $\delta^{13} \mathrm{C}$ and $\delta^{18} \mathrm{O}$ are plotted against depth (Fig. 8). Results from Site 892 (represented by diamonds in Fig. 8A) show a distinct carbon isotope trend from about $-52 \%$ o PDB to around $+15 \%$ PDB downhole. $\delta^{18} \mathrm{O}$ reflects typical isotopic composition of marine cold-water carbonate. Strong depletions in ${ }^{18} \mathrm{O}$ are only found at the depths of $62-67 \mathrm{mbsf}$ and around 105 mbsf, corresponding to a prominent fault zone and a shear zone respectively (Fig. 8B). For Sites 889 and 891 , no comparable correlations were observed. At Sites 889 and 891 , variations in both carbon and oxygen isotope signatures do not appear to mirror structural observations (possible fluid conduits). Values for both $\delta^{13} \mathrm{C}$ and $\delta^{18} \mathrm{O}$ vary in a narrow range.

\section{DISCUSSION}

\section{Deformational Fabrics and Strain}

Strain estimates via the Fry and PODI techniques recorded on carbonate concretions showed no distinct increase of strain downhole (Table 1). Obviously, all calculated strain values distinctly exceed aspect ratios $\left(R_{f}\right)$ of 1.0; therefore, we conclude that concretions were not formed at or near the sediment-water interface. According to studies of Oertel and Curtis (1972) or Behrmann and Kopf (1993) on 
Table 6. Carbon and oxygen stable isotope mass spectrometry data from 29 samples from Sites 889,891 , and 892.

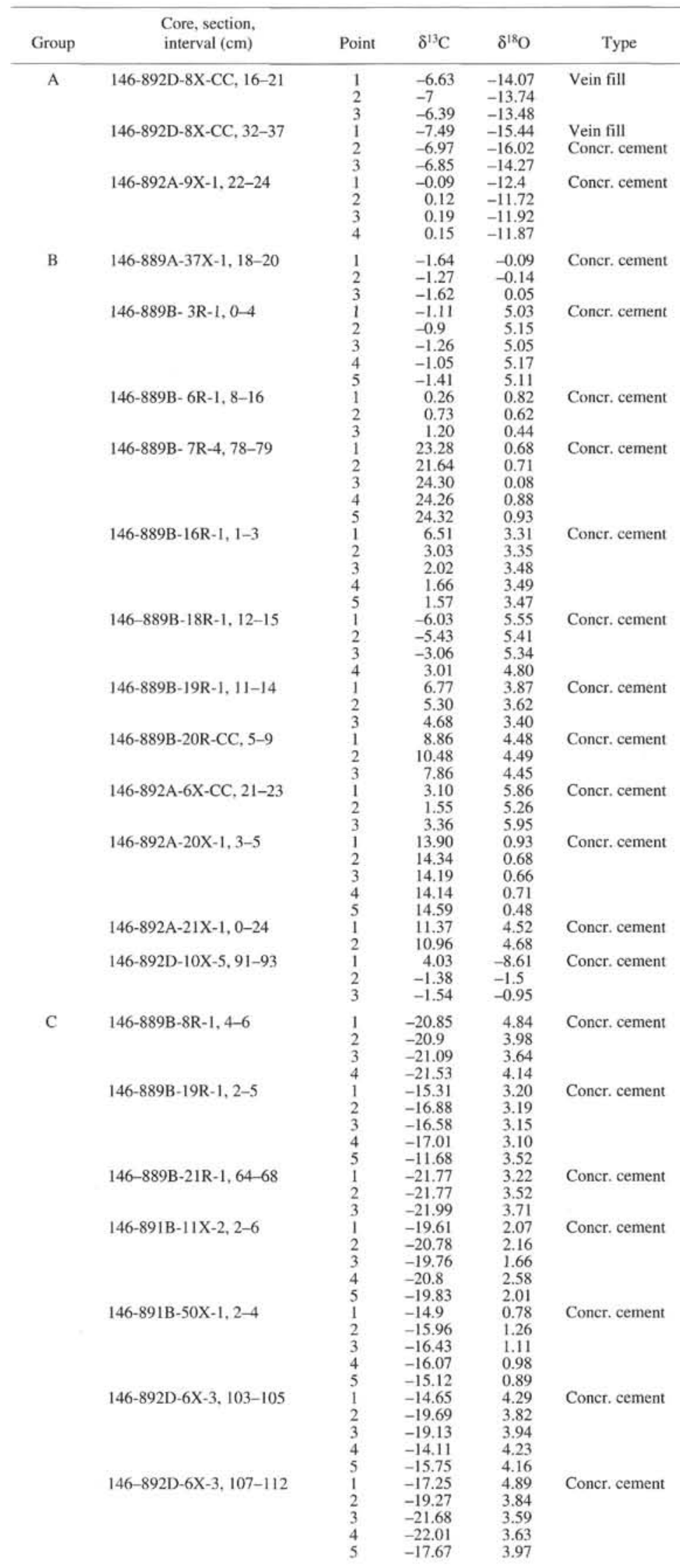


Table 6 (continued).

\begin{tabular}{|c|c|c|c|c|c|}
\hline Group & $\begin{array}{l}\text { Core, section, } \\
\text { interval }(\mathrm{cm})\end{array}$ & Point & $\delta^{13} \mathrm{C}$ & $\delta^{18} \mathrm{O}$ & Type \\
\hline \multirow[t]{6}{*}{ D } & $146-892 \mathrm{~A}-3 \mathrm{X}-2,99-101$ & $\begin{array}{l}1 \\
2 \\
3\end{array}$ & $\begin{array}{l}-35.38 \\
-28.02 \\
-30.81\end{array}$ & $\begin{array}{l}4.64 \\
4.61 \\
4.75\end{array}$ & Concr. cement \\
\hline & $146-892 \mathrm{~A}-4 \mathrm{X}-1,4-5$ & $\begin{array}{l}1 \\
2 \\
3 \\
4 \\
5\end{array}$ & $\begin{array}{l}-34.61 \\
-34.72 \\
-34.57 \\
-34.95 \\
-34.48\end{array}$ & $\begin{array}{l}5.06 \\
5.31 \\
5.17 \\
4.87 \\
4.97\end{array}$ & Concr. cement \\
\hline & $146-892 \mathrm{D}-2 \mathrm{X}-4,88-90$ & $\begin{array}{l}1 \\
2 \\
3 \\
4 \\
5\end{array}$ & $\begin{array}{l}-40.52 \\
-41.31 \\
-41.03 \\
-40.17 \\
-40.07\end{array}$ & $\begin{array}{l}4.84 \\
4.64 \\
4.65 \\
4.76 \\
4.86\end{array}$ & Concr. cement \\
\hline & $146-892 D-4 X-1,0-2$ & $\begin{array}{l}1 \\
2 \\
3 \\
4 \\
5\end{array}$ & $\begin{array}{l}-51.00 \\
-51.29 \\
-51.74 \\
-52.03 \\
-51.48\end{array}$ & $\begin{array}{l}5.41 \\
5.26 \\
5.35 \\
5.43 \\
5.38\end{array}$ & Concr. cement \\
\hline & $146-892 D-12 X-2,142-144$ & $\begin{array}{l}1 \\
2 \\
3 \\
4 \\
5\end{array}$ & $\begin{array}{l}-36.55 \\
-37.63 \\
-37.65 \\
-37.54 \\
-36.83\end{array}$ & $\begin{array}{l}4.27 \\
3.85 \\
4.03 \\
3.91 \\
4.32\end{array}$ & Concr. cement \\
\hline & $146-892 \mathrm{E}-1 \mathrm{X}-2,74-76$ & $\begin{array}{l}1 \\
2 \\
3 \\
4 \\
5\end{array}$ & $\begin{array}{l}-41.84 \\
-48.34 \\
-39.47 \\
-40.55 \\
-37.32\end{array}$ & $\begin{array}{l}4.88 \\
5.34 \\
4.92 \\
4.92 \\
5.07\end{array}$ & Concr. cement \\
\hline
\end{tabular}

Notes: Values are reported in the familiar delta notation relative to the PDB standard for both $\delta^{13} \mathrm{C}$ and $\delta^{18} \mathrm{O}$. Data can be divided into four groups: $\mathrm{A}=\mathrm{specimens}$ from fault zone at about 70 mbsf at Site 892 , showing stronger fractionation for $\delta^{18} \mathrm{O} ; \mathrm{B}=$ specimens from Sites 889 and 892 characterized by depletion in ${ }^{13} \mathrm{C}$ and by oxygen isotopic signatures similar to modern ocean water; $\mathrm{C}=$ specimens from Sites 889,891 and 892 reflecting thermogenic maturation of carbon; and D = specimens from the uppermost sediments at Site 892 , with $\delta^{13} \mathrm{C}$ signatures reflecting a composition of dominantly thermogenic carbon sources probably mixed with minor amounts of biogenically produced methane.

marine sediments, large reduction of pore space from clay fabric collapse occurs under only a few tens of meters of overburden. Strains inferred from distortion of marker particles allow us to interpret the textures as the "frozen" fabric of the sediment during carbonate precipitation. Strain data range between 1.2 and 1.71 for $\mathrm{R}_{\mathrm{f}}$, and reflect distinct amounts of settling in the sediment before carbonate grain cements were precipitated. Porosity loss caused by compaction implies vertical shortening $\left(e_{z}\right)$ between $17 \%$ and $42 \%$ (Table 1). If we assume initial porosities from $50 \%$ (silts and clayey silts) to around $70 \%$ (dominantly clays) for unconsolidated marine near-surface sediments, significant amounts of the disposable porosity had been lost by vertical shortening before cementation. Although it is impossible to determine the depth of carbonate formation by means of strain values precisely (see discussion in Behrmann and Kopf, 1993), precipitation evidently took place at depths of at least a few tens of meters below seafloor. Although both in situ observations (Westbrook, Carson, Musgrave, et al., 1994) and our data reveal no evidence for late diagenetic influences on carbonate concretions because of enlarged loading and/or temperature downhole, carbonate contents as high as $>70 \%$ were determined by XRF, XRD, and electron microprobe.

Authigenic carbonates initially precipitated as high-Mg calcite, Ca-rich dolomite and protodolomite, or even complex carbonates makes dolomitization an unlikely cause to raise the volumetric carbonate abundance in the concretions. On the other hand, no indications for carbonate displacement or dissolving and recrystallization processes are found by thin section observations. Textural data suggest that the carbonate minerals formed as a single phase of diagenetic crystallization, and, less likely, as a result of repeated recrystallization and phase changes. But despite possible displacement or exchange of detrital components by carbonate, our strain estimations with good quality plots evidently reflect initial settling showing preserved fossil shells (partially unbroken, both aragonite and calcite) and fresh glaucony grains. Uncertainties concerning the immobility of organic matter exist (see "Methods" section, this chapter), but values for vertical shortening found with opaques (ores, organic matter) range in the same order as those by other marker particles (Table 1) and therefore were also acceptable. Concretions may have maintained substitutional processes with their surroundings as an open system, but no evidence for displacement or rearrangement of the selected marker particles could be found.

Formation of microfractures is the most common observation in carbonate concretions from Sites 889, 891, and 892. More intense fracturing to complete destruction of the concretionary framework was found for some of the concretions taken at Site 892 (cf. Pl. 1, Fig. 4). Those samples correspond to the depth of a prominent fault zone (62-67 mbsf). Different mechanisms for fragmentation are envisaged. Brecciation thrusting and shearing in the vicinity of faults could lead to the observed fractures completely separating concretions. Generally, sediments drilled at Site 892 have undergone the most intense deformation in comparison to the other sites drilled during Leg 146 (Westbrook, Carson, Musgrave, et al., 1994; Tobin et al., this volume). Brecciation of some of the concretions indicates elevated mechanical stresses along the fault plane, and it reflects the maximum of deformation found at Site 892 . However, veins and microfractures that do not intersect the surfaces of concretions cannot be explained by this mechanism. These fractures within the concretionary framework require overpressuring of enclosed pore fluids, exceeding both the tensional strength and the lithostatic load imposed by the hanging-wall material. Generally, two scenarios can be envisioned: The first possibility is a model of a "hydrostatic" state where the effective mean stress is equal to the tensile strength of the concretion. Assuming this model, hydrofractures will nucleate around mechanical zones of weakness inside the concretion. The other possibility is a tectonic model, where $\sigma 1$ and $\sigma 3$ are the directions of maximum and minimum effective principal stresses. In a thrust regime, tensile fractures will develop if the vertical load is lowered. While during thrust faulting hydrofracture always requires fluid pressures in excess of lithostatic load, shallow-level wrench faulting and normal faulting permits simultaneous hydrofracture and shearing at fluid pressures significantly lower than lithostatic loading (e.g., Sibson, 1981; Behrmann, 1991). Different mechanisms for abrupt decrease of lithostatic loading are conceivable. First, material may be removed as megaslumps (von Huene et al., 1989). Second, lithostatic load may also be lowered by uplift from thrust stacking caused by 


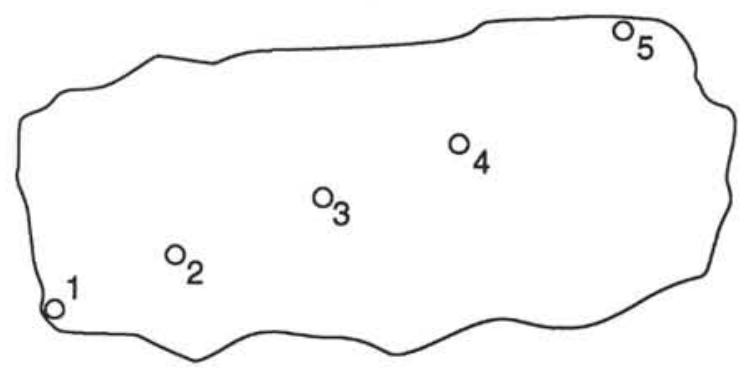

Figure 7. Zonation of carbon and oxygen stable isotopic signature inside a carbonate concretion (Sample 146-892D-6X-3, 107-112 cm). Evidence for higher degrees of fractionation for both $\delta^{13} \mathrm{C}$ and $\delta^{18} \mathrm{O}$ measurements, respectively, is observed in the central area (points 2 and 3). The concretion is about $45 \mathrm{~mm}$ in diameter.

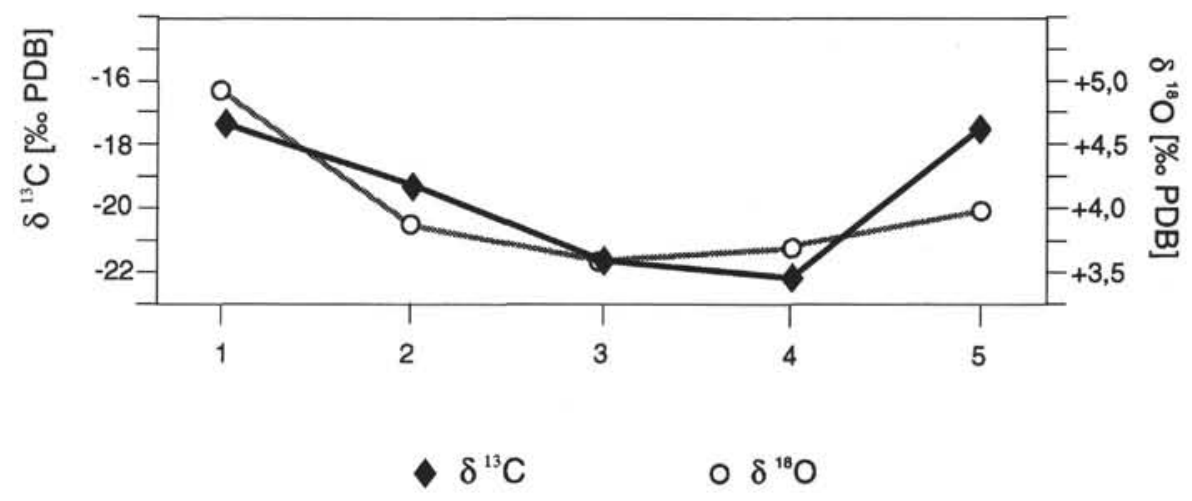

sustained frontal accretion or submarine erosion of the overburden. The third possible explanation for lowered lithostatic load is the upward transfer of material along faults or fault zones. A fourth general possibility of evolution of fractures inside a concretion may be volume loss during non-isochemical recrystallization of calcite, aragonite, ankerite, or magnesian calcite. For example, complete dolomitization of calcite is accompanied by a $13 \%$ volume loss, which could lead to fracture porosity.

The transformation of calcite (or other authigenic carbonate) to dolomite at best could have played only a subordinate role, because textural evidence for dolomitization caused by incipient diagenesis was not found and because fracture porosity of several concretions far exceeds $20 \%$. Authigenic carbonates initially precipitated as high$\mathrm{Mg}$ calcite, Ca-rich dolomite and protodolomite, or even complex carbonates could explain small volume loss from possible dolomitization. Removal of the overburden by megaslumps or erosion can be excluded from in situ observations (Westbrook, Carson, Musgrave, et al., 1994). On the other hand, sediments from Site 892 deposited in a lower bathyal depth range of about $2000-4000$ mbsf (cf. Resig, 1990) have undergone a significant large-scale uplift since Pliocene times. Now below $\sim 670 \mathrm{~m}$ of water, these sediments with ages less than 5 Ma have recorded at least $1400 \mathrm{~m}$ of uplift. The intense vertical movements are correlated with the appearance and subduction of the landward flank of the Juan de Fuca spreading ridge on the one hand, and progressive frontal accretion followed by thrust-related landward rotation and uplift inside the accretionary wedge on the other hand. Strong uplift lowers lithostatic and/or hydrostatic pressure and, thus, provides a mechanism for development of hydrofractures. Moreover, the most mature structural fabrics recovered at Leg 146 were observed at Site 892 (Westbrook, Carson, Musgrave, et al., 1994). The foot-wall section especially shows a wide range of deformation features including stratal disruption, zones exhibiting broken and dispersed cemented sediments, "mélange fabrics" of pervasive anastomosing shear zones, intervals of scaly fabric with open fracture systems and polished and slickened surfaces, sets of deformation bands through the entire section, and microscale to mesoscale folding. As mentioned earlier, only the prominent fault zone $(62-67 \mathrm{mb}-$ sf) contained concretions where both brecciation and hydrofractures were found. The intense fragmentation of the concretions implies that material has probably underlain migration from the deeper part of the prism, showing both brittle deformation and brecciation shear stress along the fault plane plus hydrofracture as a result of lowered lithostatic load. Together with the exceptional chemical compositions (see below), upward migration of both sedimentary rocks and fluids is suggested.

\section{Chemical Composition and Isotopic Signatures of Carbonate Concretions}

Optical petrography has revealed both dominance of carbonate minerals in micritic to sparitic concretionary cements and occurrence of subordinate amounts of detrital carbonate in soft to indurated sediments. Contents of diagenetic carbonate vary strongly, with an average $60-65$ vol\% (Table 3). Carbonate abundance depends mainly on grain size of the initial marine deposits and on the amount of detrital quartz, feldspar, and carbonate. Low content of authigenic carbonate largely is caused by an enhanced amount of detrital components (Sample 146-889B-11X-2, 2-6 cm, Pl. 1, Fig. 3). On the other hand, carbonate content just below $80 \mathrm{vol} \%$ requires particular assumptions to explain solely as cementation process inside the sediment pile. If initial porosities are assumed to be $70 \mathrm{vol} \%$ or more for muds and clays, and it is presumed that unconsolidated sediment has undergone only little pore space collapse before carbonate precipitation took place (see discussion on strain data above), only low primary carbonate content is necessary to correspond even with values $>70 \mathrm{vol} \%$ carbonate from petrographic observations. In smear-slide analyses carried out during Leg 146 (Westbrook, Carson, Musgrave, et al., 


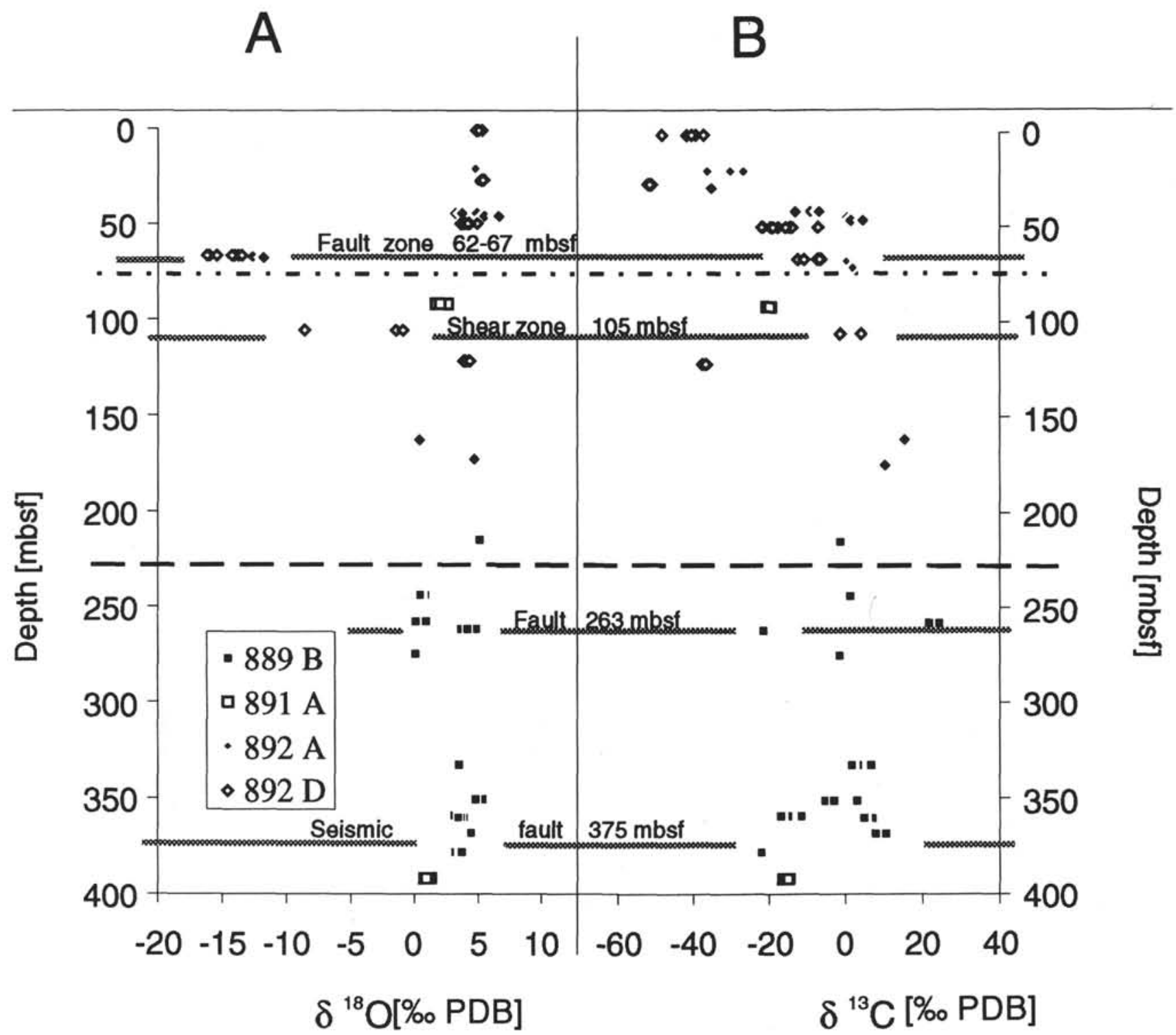

BSR : $\cdots \cdots-189 \cdots \cdots-892$

Figure 8. A. $\delta^{13} \mathrm{C}$ (in \%o PDB) isotopic signature vs. depth showing measurements on mainly carbonate concretions. B. $\delta^{18} \mathrm{C}$ (in \%o PDB) isotopic signatures vs. depth on same set of samples. Horizontal lines mark the level of the BSR, according to drilling results (Westbrook, Carson, Musgrave, et al., 1994) from Sites 892 (67.7 mbsf) and 889 (225 mbsf). See data in Table 5 and text for discussion.

1994), visual estimations for detrital calcite and dispersed rhombs of dolomite ranged between $5 \%$ and $15 \%$ of rock volume. In addition, variable content of nannofossils, foraminifers, and other shell fragments (about 5 vol\% on average) should be added. Total carbonate content measured takes into account the presumed sedimentary carbonate, so that neither replacement nor cement displacement are necessary to explain high carbonate content, and cementation in situ preserves the original mud fabric.

Results of XRF and XRD measurements show dominance of $\mathrm{CaCO}_{3}$ and $\mathrm{MgCO}_{3}$ with composite contents $\left(\Sigma=\mathrm{CaO}, \mathrm{MgO}, \mathrm{CO}_{2}\right)$ higher than $90 \mathrm{wt} \%$. XRD patterns of almost all concretions showed characteristic shifts of the calcite- $\left(\mathrm{d}_{104}\right)$-peak, displaying high-Mg calcite ranging between $8-22$ mole $\% \mathrm{MgCO}_{3}$. Those results agree perfectly with earlier work on dredged carbonates at the Oregon forearc, where Ritger and others (1987) found values ranging from 623 mole $\% \mathrm{MgCO}_{3}$ in $\mathrm{Mg}$ calcites. About $80 \%$ of the carbonate concretions show compositions of high- $\mathrm{Mg}$ calcite, while remaining samples consist either of $\mathrm{CaCO}_{3}$ and $\mathrm{MgCO}_{3}$ in equal proportions (as Ca-rich dolomite-like material, or protodolomite) or of complex carbonate associations with $\mathrm{Fe}^{2+}, \mathrm{Mn}^{2+}, \mathrm{Ca}^{2+}$, and $\mathrm{Mg}^{2+}$ as main substituting cations. Although the precipitation of complex carbonates is poorly understood, their formation can be roughly estimated by taking the diagenetic environment into account (Tassé and Hesse, 1984). The presence of the cations is largely controlled by the sedimentation rates, because nitrate, sulfate, and carbonate serve as oxygen donors for microbial oxidation of buried organic matter (Gieskes and Lawrence, 1981). Initially, $\mathrm{Mg}^{2+}$ dominates the pore fluid and as long as the $\mathrm{Mg} / \mathrm{Ca}$ ratio is greater than 1 , any $\mathrm{Mg}^{2+}$ decrease can be related 
Figure 9. Stable carbon isotopes versus oxygen isotopes from Sites 889, 891, and 892. Groups AD correspond to those of Table 5. See text.

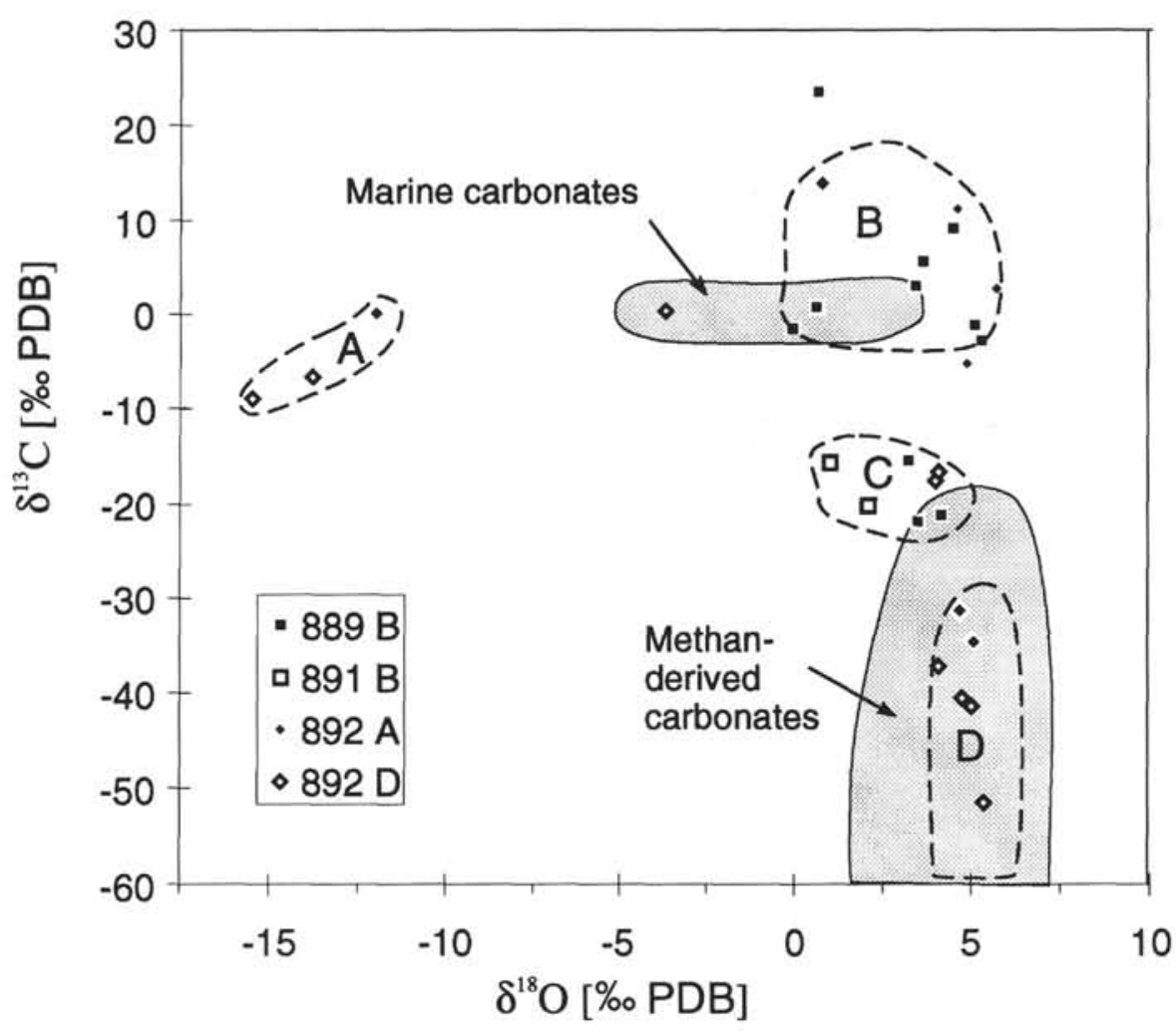

to the precipitation of dolomite and complex carbonates (e.g., Kelts and McKenzie, 1982). Inorganic chemistry during Leg 146 showed $\mathrm{Mg} / \mathrm{Ca}$ profiles with depth that do not remain $<1$ for all sites (Westbrook, Carson, Musgrave, et al., 1994). Marked decreases of $\mathrm{Mg}^{2+}$ deeper in the section are observed at Sites $889 / 890$ (below $180 \mathrm{mbsf}$ ), 891 (below $190 \mathrm{mbsf}$ ), and 892 (below the fault zone at $67 \mathrm{mbsf}$ ), but only inaccurate correlations with precipitation of high-Mg calcite, dolomite, and complex carbonates are found. The depletion of $\mathrm{Mg}^{2+}$ reflects both transformation and recrystallization of clay minerals and contribution to dolomite formation (Baker and Kastner, 1981) while the enrichment in $\mathrm{Ca}^{2+}$ is controlled by reactions with plagioclase, amphibole, and pyroxene (e.g., from volcanic ash layers, (cf. Gieskes and Lawrence, 1981), or dissolution of biogenic carbonate in deeper parts of the sediment pile. $\mathrm{Mn}^{2+}$ and $\mathrm{Fe}^{2+}$ commonly are mobilized from oxides and hydroxides in the sediment under reducing conditions.

Summing up the results of electron microprobe analysis for Site 892 , we found that distinct differences exist in carbonate contents between samples thought typical for the Cascadia forearc and those from the fault zone (Table 5). Authigenic high-magnesian calcite and complex carbonates (in minor amounts) are dominant in both matrix and vein cements of characteristic concretions (Figs. 5, 6, and Table 4). Our chemical data generally are in accord with sedimentological and smear-slide observations aboard JOIDES Resolution, where carbonate concretions showed continuously weak reactions to hydrochloric acid, which suggests $\mathrm{Mg}^{2+}$ enrichment of the carbonate cements (Westbrook, Carson, Musgrave, et al., 1994). In the fault zone at Site 892 (62-67 mbsf), almost pure calcite with distinct contents of $\mathrm{MnCO}_{3}$ (up to $2.59 \mathrm{wt} \%$ ) and $\mathrm{FeCO}_{3}$ (up to $1 \mathrm{wt} \%$ ) display complex carbonate precipitation, and also suggest the upward migration of fluids from a different reservoir. Those fluids may be related to deeper levels in the prism because of the enrichment in $\mathrm{Mn}^{2+}$ and $\mathrm{Fe}^{2+}$. In addition, the precipitation of pure calcite is also found at sev- eral depths of small faults or fluid conduits at Site 891 (cf. Sample and Kopf, this volume).

The isotopic signatures of authigenic carbonate cements is an additional and useful method to constrain chemical compositions, petrographic observations, and the history of fluid flow in accretionary prisms. The importance of fault zones and possible fluid conduits was indicated by differences in chemical and mineralogical compositions as outlined above. Carbon isotope ratios increase downhole, showing the strongest depletion of ${ }^{13} \mathrm{C}$ in the hanging-wall section of the sediment pile (Fig. 8A). A large set of samples reflect typical signatures for modern marine carbonates, showing $\delta^{13} \mathrm{C}$ values between $-6 \%$ and $+6 \%$ PDB (Table 6, Groups A and B; cf. also Fig. 9). Fewer samples of that group display unusual enrichment of ${ }^{13} \mathrm{C}$ for a continentalmargin setting (up to $+25 \%$ PDB). One possible source for the heavy $\mathrm{C}$-isotopes may be $\mathrm{CO}_{2}$ formed by disproportionation reactions of $\mathrm{CO}_{2}$ during methanogenesis below the base of the sulfate reduction zone (Claypool and Kaplan, 1974). An interpretation of isotope values caused by fermentation reaction is confirmed by enriched ${ }^{13} \mathrm{C}$ values of $\mathrm{CO}_{2}$ from a large number of gas analyses taken at Site 892 (Whiticar and Hovland, this volume) and agrees also with a shallow fluid source in the accretionary prism (Westbrook, Carson, Musgrave, et al., 1994). Depletion in ${ }^{13} \mathrm{C}$, reflected by another set of concretions (Table 6, Group C; Fig. 9) ranging between $-22 \%$ to $-5 \%$ o PDB, characterizes methane-derived carbonates (e.g., Claypool et al., 1985). Depletion of ${ }^{13} \mathrm{C}$ is a characteristic possibly indicating a source of thermogenic methane (Vinogradov and Galimov, 1970). Almost all concretions from that group were taken from deeper levels than found for thermogenic hydrocarbons (Westbrook, Carson, Musgrave, et al., 1994); however, thermogenic methane could have been present at shallower levels in the past. Strong depletions in ${ }^{13} \mathrm{C}$ that were related to oxidation of methane were also found in the uppermost sections at the Oregon sites. Light carbon isotope values between $-28 \%$ and $-52 \%$ PDB (Table 6, Group D; Fig. 9) were interpreted as pre- 
cipitates of thermogenic methane that may have been mixed with minor amounts of biogenic gas (cf. Hovland et al., 1987; Sakai et al., 1992). These signatures are restricted to shallow levels in the accretionary prism of Site 892 (Fig. 8A) and are probably a result of microbial decomposition of organic matter (e.g., Claypool et al., 1985; Kulm and Suess, 1990). Strong decrease in carbon isotope signatures in the concretions from the hanging-wall section precipitation probably did not take place in equilibrium with interstitial pore fluids. A possible conduit for biogenic fluids and gases could have been the fault zone at $62-67 \mathrm{mbsf}$ that includes brecciated, highly permeable material that allows an influx from shallow sources. Gradients in carbon isotopic signatures, as observed with decreasing values for ${ }^{13} \mathrm{C}$ toward the rim in some samples (Fig. 7), probably reflect mixing of thermogenically derived methane with a biogenic component for the later stages of precipitation.

Oxygen isotope signatures of the carbonates indicate two major trends (Fig. 8B). The majority of the material shows high oxygen isotope ratios (between $-2 \%$ and $+5.5 \%$ PDB; cf. Table 6, Groups BD), indicating precipitation from cold pore fluids with an approximate sea-water signature (e.g., Hovland et al., 1987; Sakai et al., 1992). The relatively narrow range for ${ }^{18} \mathrm{O}$-enriched carbonates coincides with a wide range in $\delta^{13} \mathrm{C}$, which is similar to results from samples taken from a bioherm at the sea floor. With respect to the observed non-systematic variations of oxygen isotopes at all sites instead of an expected decrease with increasing burial depth and temperature, our profiles imply carbonate precipitation in disequilibrium with pore fluid conditions (Fig. 8B). Exceptional results were obtained from a group of samples from the interval of the major fault zone intersected at 62-67 mbsf at Site 892. These specimens (Table 6, Group A; Fig. 9) are distinctly depleted in ${ }^{18} \mathrm{O}$, which ranges between $-13 \%$ and $-17 \%$ PDB (Fig. 8B). Light oxygen isotope ratios were found earlier in the Oregon forearc (e.g., Kulm and Suess, 1990; Sample and Reid, submitted; Sample and Kopf, this volume, which can result from different processes. Depletion of pore waters in heavy oxygen or input of meteoric fluids may be possible reasons as well as formation of gas hydrates taking in heavy oxygens from the pore fluid. Moreover, low-temperature alteration of solids in the sediment pile (Gieskes and Lawrence, 1981) or upward migration of fluids with elevated temperatures may cause depletions in ${ }^{18} \mathrm{O}$ in diagenetic carbonates. Depletion of pore fluids in ${ }^{18} \mathrm{O}$ and a likely conduit of meteoric fluids over a distance of at least $80 \mathrm{~km}$ from the continental slope to water depths around $2 \mathrm{~km}$ are both unlikely causes for the observed signatures. Alteration of volcanic matter caused by hydration reactions at low temperatures typically produces pore fluids depleted in ${ }^{18} \mathrm{O}$. These processes cannot be ruled out as an explanation because of the supply of volcanic ash from the Cascade volcanic arc, but are probably of subordinated importance here because only minor amounts of volcanic material was found during smear-slide observations (largely < 5 vol\%; cf. Westbrook, Carson, Musgrave, et al., 1994). On the other hand, no assertions concerning sediment compositions in deeper levels of the accretionary prism can be made. Formation of gas hydrates is a likely cause for depletion in ${ }^{18} \mathrm{O}$, because a well-defined BSR is found around a depth of $72 \mathrm{mbsf}$ (Westbrook, Carson, Musgrave, et al., 1994). Precipitation of authigenic carbonate in the zone of gas hydrates is supported by the depth of the samples that show lowered $\delta^{18} \mathrm{O}$ values, because all of them were found within the basal ten meters of the hydrate stability field (Fig. 8B). Finally, the contribution of warm fluids from greater depths, transported upward along the highly permeable fault zone, is another reasonable process leading to isotope ratios depleted in ${ }^{18} \mathrm{O}$. On the basis of an isotopic temperature scale (Friedman and O'Neil, 1977), pore-water temperatures during carbonate precipitation should have reached $100^{\circ} \mathrm{C}$ (see also Sample and Kopf, this volume). Drilling at Site 892 did not reveal such elevated temperatures, but did show temperature anomalies at the base of the fault zone. Assuming a geothermal gradient of $50^{\circ}$ per km (Westbrook, Carson, Musgrave, et al., 1994), a fluid reservoir at a depth of at least $2 \mathrm{~km}$ is indicated for the source of the carbonate-concentrating fluids. Isotopic $\delta^{18} \mathrm{O}$ zonation of the concretions are also present (Fig. 7), displaying significant changes in depletion of ${ }^{18} \mathrm{O}$ towards the center of the concretions. Variations most likely can be explained by different pore water temperatures during carbonate precipitation. Taking the results of the whole set of samples into account, no systematic variation from the center to the rim of the concretions could be found (cf. Table 6). However, both zonation patterns of the concretions and partially elevated paleotemperatures suggest an episodic supply of fluid from different sources.

Combined carbon and oxygen isotope signatures for carbonate cements related to the prominent fault zone at Site 892 reflect a deep, warm fluid source that is consistent with moderate depletions in ${ }^{13} \mathrm{C}$, typical for thermogenic methane. Conversely, authigenic carbonates enriched in ${ }^{13} \mathrm{C}$ coincidentally show an enrichment in ${ }^{18} \mathrm{O}$. Thus, a fluid reservoir at shallow depths displays fermentation processes and precipitation in modern marine cold-water environment.

\section{CONCLUSIONS}

1. High-Mg calcite dominates both carbonate concretions and sediments and reaches near-dolomitic composition in a few cases at greater depths. High carbonate content (up to $>80$ $\mathrm{vol} \%$ ) is caused by large initial porosities ( 50 to $>70 \mathrm{vol} \%$, depending on grain size of sediment) and moderate to high primary sedimentary carbonate content $(5-20 \mathrm{vol} \%)$ of the forearc sediments. Porosity reduction is caused by both collapse of pore space and precipitation of carbonate from fluids. Magnesian calcite content ranges between $8 \%$ and $22 \%$ mole $\mathrm{MgCO}_{3}$, which is in good agreement with previous studies from the same area (Ritger et al., 1987; Kulm and Suess, 1990).

2. Shearing and hydrofracturing of concretions is believed to originate from different mechanisms. Concretions taken from the vicinity of the fault zone at Site 892 are broken and brecciated during shearing. Fractures and veins terminating within the concretions are believed to be caused by hydrofracture lowered lithostatic load. In a few cases, additional fracture porosity may have been generated by dolomitization.

3. Position fabrics of immobile markers in the concretions yielded variable values for uniaxial shortening compaction. These results imply porosity loss during the initial stages of normal gravitational loading prior to carbonate precipitation. An important conclusion from this is that the concretions were generated within the sediment pile under shallow overburden (at least a few tens of meters) and not at the sediment-water interface.

4. Stable carbon isotope signatures typically reflect a composition ranging from common marine carbonate to significant depletion in ${ }^{13} \mathrm{C}$ oxidation of thermogenic methane and incorporation of methane carbon. An admixture of distinct amounts of biogenic methane (reflected in values of less than $-50 \%$ o PDB) seems conceivable. Enrichment of ${ }^{13} \mathrm{C}$ in a few cases most likely corresponds to fermentation reactions in shallow levels of the accretionary prism. Oxygen isotopic signatures indicate that precipitation of authigenic carbonates occurred from cold pore waters. Exceptionally ${ }^{18} \mathrm{O}$-depleted isotope signatures found at Site 892 correlate with the depths of a prominent fault zone and shear zone, suggesting the upward migration of warm fluids from deeper levels along these structures. 
5. The material from the fault zone at Site 892 has different chemical and oxygen isotopic compositions. Sediments are more indurated, showing authigenic carbonates precipitated as cements or vein fills that consist mainly of pure calcite. Thus, it may be concluded that both transport of sedimentary material and fluid from a different reservoir occurs along the thrust system at Site 892 .

\section{ACKNOWLEDGMENTS}

G. Bohrmann, E. Suess, and P. Frolic are acknowledged for their helpful reviews and detailed suggestions. A. Hoffman, N. Gleis, and P. Zinn are thanked for their help carrying out XRF and XRD measurements. Thanks are extended also to H.H. Cord and H. Heckt for taking care of the isotope analyses. Support for this research was provided by the Deutsche Forschungsgemeinschaft through grant $\mathrm{Be}$ 1041/8-1 to JHB. Kopf thanx Khaki for a wonderful time aboard and making good friends.

\section{REFERENCES}

Baker, P.A., and Kastner, M., 1981. Constraints on the formation of sedimentary dolomite. Science, 213:215-216.

Bangs, N.L.B., Sawyer, D.S., and Golovchenko, X., in press. The cause of the bottom-simulating reflection in the vicinity of the Chile Triple Junction. In Lewis, S.D., Behrmann, J.H., Musgrave, R.J., Cande, S.C. (Eds.), Proc. ODP, Sci. Results, 141: College Station, TX (Ocean Drilling Program).

Behrmann, J.H., 1991. Conditions for hydrofracture and the fluid permeability of accretionary wedges. Earth Planet. Sci. Lett., 107:550-558.

Behrmann, J.H., and Kopf, A., 1993. Textures and microfabrics in finegrained muds and mudstones from Site 808, Nankai accretionary prism. In Hill, I.A., Taira, A., Firth, J.V., et al., Proc. ODP, Sci. Results, 131: College Station, TX (Ocean Drilling Program), 45-56.

Carson, B., Westbrook, G.K., and Musgrave, R.J., 1993. Ocean Drilling Program Leg 146 Preliminary Report-Cascadia Margin. ODP Prelim. Rep., 46.

Claypool, G.E., and Kaplan, I.R., 1974. The origin and distribution of methane in marine sediments. In Kaplan, I.R. (Ed.), Natural Gases in Marine Sediments: New York (Plenum), 99-139.

Claypool, G.E., Threkheld, C.N., Mankiewicz, P.N., Arthur, M.A., and Anderson, F.T., 1985. Isotopic composition of interstitial fluids and origin of methane in slope sediment of the Middle America trench, Deep Sea Drilling Project Leg 84. In von Huene, R., Aubouin, J., et al., Init. Repts. DSDP, 84: Washington (U.S. Govt. Printing Office), 683-691.

Clayton, R.N., 1961. Oxygen isotope fractionation between calcium carbonate and water. J. Chem. Phys., 34:724-726.

Craig, H., 1957. Isotopic standards for carbon and oxygen and correction factors for mass-spectrometric analysis of carbon dioxide. Geochim. Cosmochim. Acta, 12:133-149.

Demets, C., Gordon, R.G., Argus, D.F., and Stein, S., 1990. Current plate motions. Geophys. J. Int., 101:425-478.

Friedman, I., and O'Neil, J.R., 1977. Compilation of stable isotope fractionation factors of geochemical interest. In Fleischer, M. (Ed.), Data of Geochemistry (6th ed.). Geol. Surv. Prof. Pap. U.S., 440-KK:1-12.

Fry, N., 1979. Density distribution techniques and strained length methods for determination of finite strains. J. Struct. Geol., 1:221-229.

Füchtbauer, H., and Müller, G., 1977. Sedimente und Sedimentgesteine (3rd ed.): Stuttgart (Schweizerbart).

Gieskes, J.M., and Lawrence, J.R., 1981. Alteration of volcanic matter in deep-sea sediments: evidence from the chemical composition of interstitial waters from deep sea drilling cores. Geochim. Cosmochim. Acta, 45:1687-1703.

Goldsmith, J.R., Graf, D.L., and Heard, H.C., 1961. Lattice constants of the calcium-magnesium carbonates. Am. Mineral., 46:453-457.

Higgins, I.J., and Quale, J.R., 1970. Oxygenation of methane by methanegrown Pseudomonas methanica and Methanomonas methanooxidans. Ukr. Biokhim. Zh., 118:201-208.

Hovland, M., Talbot, M.R., Qvale, H., Olaussen, S., and Aasberg, L., 1987. Methane-related carbonate cements in pockmarks of the North Sea. J. Sediment. Petrol., 57:881-892.
Hsü, K.J., 1968. Principles of mélanges and their bearing on the FranciscanKnoxville paradox. Geol. Soc. Am. Bull., 79:1063-1074.

Hyndman, R.D., and Davis, E.E., 1992. A mechanism for the formation of methane hydrate and seafloor bottom-simulating reflectors by vertical fluid expulsion. J. Geophys. Res., 97:7025-7041.

James, N.P., and Choquette, P.W., 1983. Diagenesis 6: Limestones: the seafloor diagenetic environment. Geosci. Can., 10:162-179.

Kelts, K., and McKenzie, J.A., 1982. Diagenetic dolomite formation in Quaternary anoxic diatomaceous muds of Deep Sea Drilling Project Leg 64, Gulf of California. In Curray, J.R., Moore, D.G., et al., Init. Repts. DSDP, 64 (Pt. 2): Washington (U.S. Govt. Printing Office), 553-569.

Kulm, L.D., and Suess, E., 1990. Relationship between carbonate deposits and fluid venting: Oregon accretionary prism. J. Geophys. Res., 95:8899-8915.

Kvenvolden, K.A., and Barnard, L.A., 1983. Gas hydrates of the Blake Outer Ridge, Site 533, Deep Sea Drilling Project Leg 76. In Sheridan, R.E., Gradstein, F.M., et al., Init. Repts.DSDP, 76: Washington (U.S. Govt. Printing Office), 353-365.

Kvenvolden, K.A., and Kastner, M., 1990. Gas hydrates of the Peruvian outer continental margin. In Suess, E., von Huene, R., et al., Proc. ODP, Sci. Results, 112: College Station, TX (Ocean Drilling Program), 517526.

Kvenvolden, K.A., and McMenamin, M.A., 1980. Hydrates of natural gas: a review of their geologic occurrence. Geol. Surv. Circ. (U.S.), 825.

MacKay, M.E., Moore, G.F., Cochrane, G.R., Moore, J.C., and Kulm, L.D., 1992. Landward vergence and oblique structural trends in the Oregon margin accretionary prism: implications and effect on fluid flow. Earth Planet. Sci. Lett., 109:477-491.

Moore, J.C., Orange, D., and Kulm, L.D., 1990. Interrelationship of fluid venting and structural evolution: Alvin observations from the frontal accretionary prism. J. Geophys. Res., 95:8795-8808.

Müller, H., and Mingram, B., 1993. Gneisses of the KTB Vorbohrung and Hauptbohrung, II. Source rocks and petrogenesis. In Emmermann, R., Lauterjung, J., and Umsonst, T. (Eds.), KTB Rep., 93-2:75-78.

Norrish, K., and Hutton, J.T., 1969. An accurate X-ray spectrographic method for the analysis of a wide range of geological samples. Geochim. Cosmochim. Acta, 33:431-453.

Odin, G.S., 1985. Significance of green particles (glaucony, berthierine, chlorite) in arenites. In Zuffa, G.G. (Ed.), Provenance of Arenites: Berlin (Reidel), 279-307.

Oertel, G., and Curtis, C.D., 1972. Clay-ironstone concretion preserving fabrics progressive compaction. Geol. Soc. Am. Bull., 83:2597-2606.

Ramsay, J.G., and Huber, M.I., 1983. The Techniques of Modern Structural Geology (Vol. 1): Strain Analysis: London (Acad. Press).

Reeburgh, W.S., 1980. Anaerobic methane oxidation: rate depth distribution in Skan Bay sediments. Earth Planet. Sci. Lett., 47:345-352.

Reeder, R.J., and Dollase, W.A., 1989. Structural variations in the dolomiteankerite solid-solution series: an X-ray, Mössbauer, and TEM study. Am. Mineral., 74:1159-1167.

Resig, J.M., 1990. Benthic foraminiferal stratigraphy and paleoenvironments off Peru, Leg 112. In Suess, E., von Huene, R., et al., Proc. ODP, Sci. Results, 112: College Station, TX (Ocean Drilling Program), 263-296.

Riddihough, R.P., 1984. Recent movements of the Juan de Fuca plate system. J. Geophys. Res., 89:6980-6994.

Ritger, S., Carson, B., and Suess, E., 1987. Methane-derived authigenic carbonates formed by subduction-induced pore water expulsion along the Oregon/Washington margin. Geol. Soc. Am. Bull., 98:147-156.

Rosenfeld, W.D., and Silverman, S.R., 1959. Carbon isotope fractionation in bacterial production of methane. Science, 130:1658-1659.

Sakai, H., Gamo, T., Ogawa, Y., and Boulegue, J., 1992. Stable isotopic ratios and origins of the carbonates associated with cold seepage at the eastern Nankai Trough. Earth Planet. Sci. Lett., 109:391-404.

Sample, J.C., Reid, M.R., Tobin, H.J., and Moore, J.C., 1993. Carbonate cements indicate channeled fluid flow along a zone of vertical faults at the deformation front of the Cascadia accretionary wedge (Northwest U.S. coast). Geology, 21:507-510.

Shackleton, N.J., 1974. Attainment of isotopic equilibrium between ocean water and the benthonic foraminifera genus Uvigerina: isotopic changes in the ocean during the last glacial. Les Meth. Quant. d'etude Var. Clim. au Cours du Pleist., Coll. Int. C.N.R.S., 219:203-209.

Sibson, R.H., 1981. Controls on low-stress hydro-fracture dilatancy in thrust, wrench and normal fault terrains. Nature, 289:665-667.

Tassé, N., and Hesse, R., 1984. Origin and significance of complex authigenic carbonates in Cretaceous black shales of the western Alps. J. Sediment. Petrol., 54:1012-1027. 
Tobin, H.J., Moore, J.C., MacKay, M.E., Orange, D.L., and Kulm, L.D. 1993. Fluid flow along a strike-slip fault at the toe of the Oregon accretionary prism: implications for the geometry of frontal accretion. Geol. Soc. Am. Bull., 105:569-582.

Unzog, W., 1990. Beispiele von Strainanalysen in Kristallingebieten. In TSK III, 3. Symposium für Tektonik, Strukturgeologie und Kristallingeologie. Kurzfassungen der Vorträge und Poster, Graz, 265-266.

Vinogradov, A.P., and Galimov, E.M., 1970. Carbon isotopes and the origin of petroleum. Geokhimiya, 3:275-296.

von Huene, R., Bourgois, J., Miller, J., and Pautot, G., 1989. A large tsunamogenic landslide and debris flow along the Peru Trench. J. Geophys. Res., 94:1703-1714.
Wada, H., Niitsuma, N., Nagasawa, K., and Okada, H., 1982. Deep sea carbonate nodules from the Middle America Trench area off Mexico, Deep Sea Drilling Project Leg 66. In Watkins, J.S., Moore, J.C., et al., Init. Repts. DSDP, 66: Washington (U.S. Govt. Printing Office), 453-474.

Westbrook, G.K., Carson, B., Musgrave, R.J., et al., 1994. Proc. ODP, Init. Repts., 146 (Pt. 1): College Station, TX (Ocean Drilling Program).

Date of initial receipt: 9 August 1994

Date of acceptance: 23 March 1995

Ms 146SR-234 

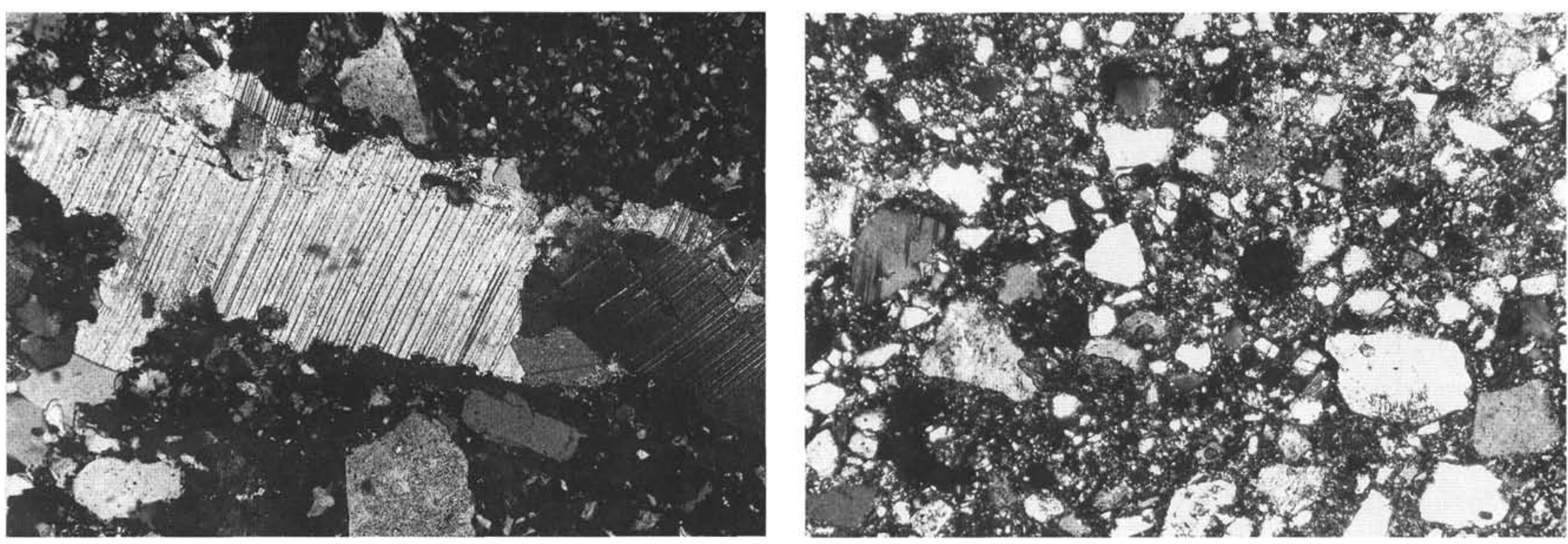

1

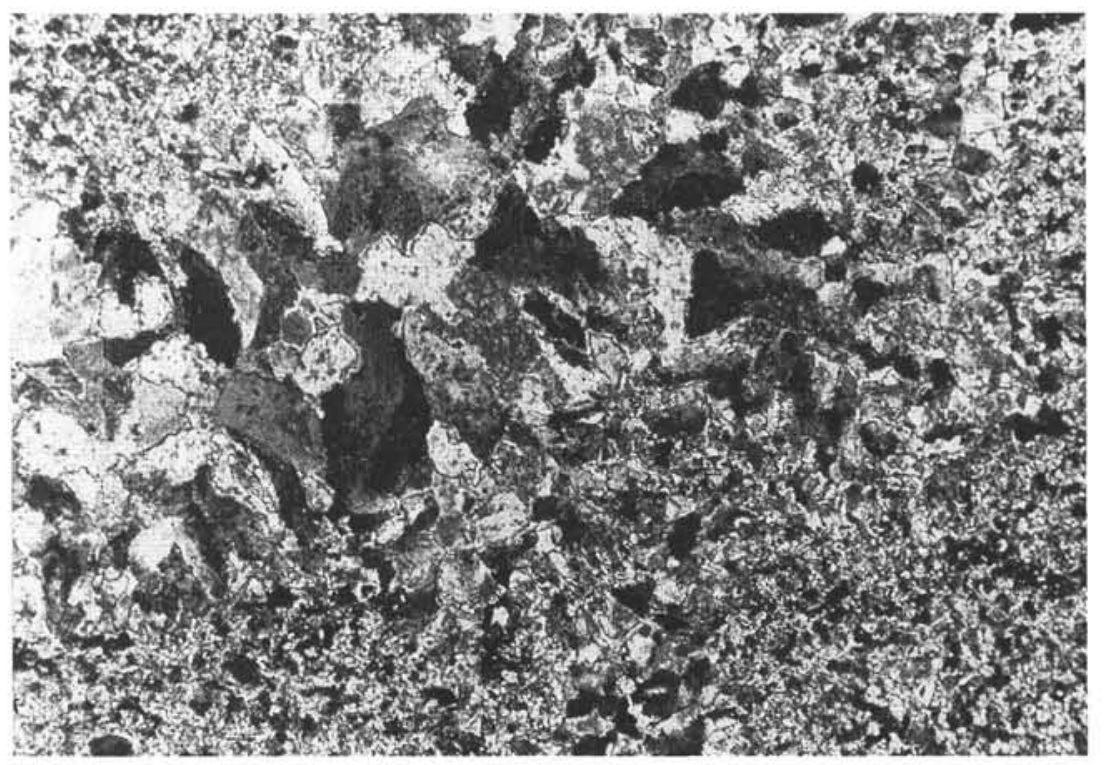

2

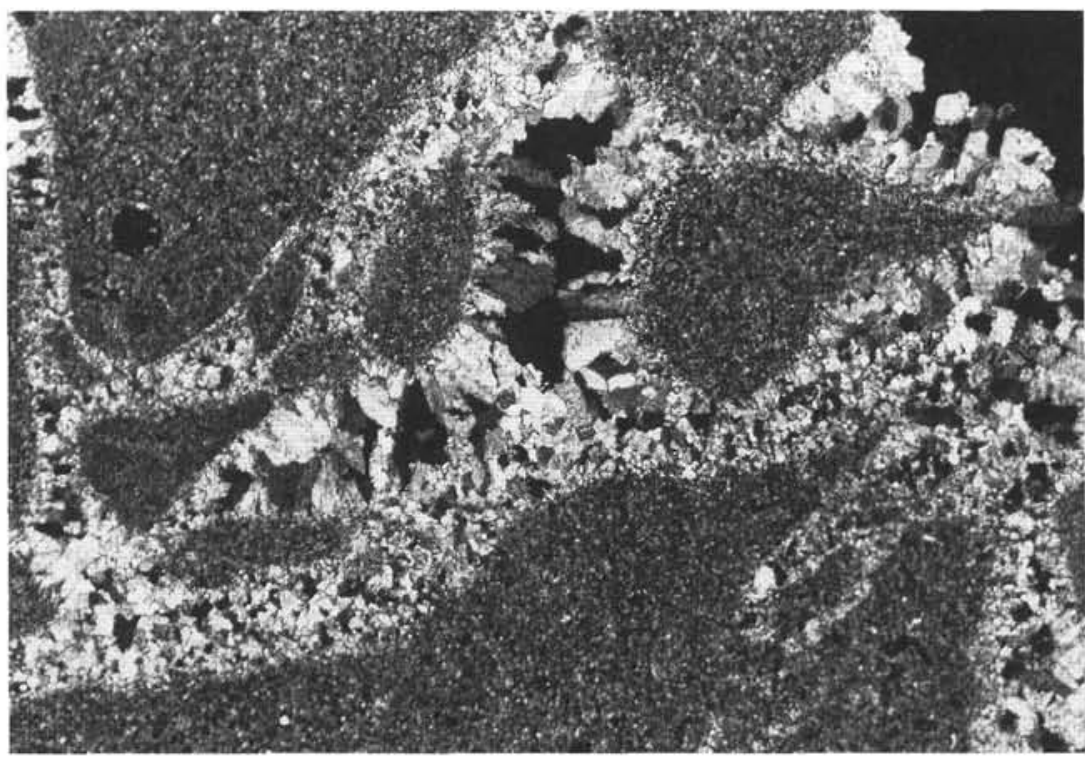
3

Plate 1. 1. Vein with twins of calcite in dark gray matrix of a lithic fragment in clayey silt (Sample 146-892D-8X-CC, 16-21 cm); long side of photomicrograph is $1.5 \mathrm{~mm}$. 2. Typical texture of a carbonate concretion with variable grain size caused by incipient lithification (Sample 146-892D-6X-3, 83-88 cm), long side of photomicrograph is $2.5 \mathrm{~mm}$.) 3. Carbonate concretion with distinct amounts of detrital quartz, carbonate, and feldspar grains (Sample 146-889B-11X-2, 2-6 cm), long side of photomicrograph is $2.5 \mathrm{~mm}$. 4. Concretion with hydrofractures filled with an early fine grained and a late coarse grained generation of carbonate cement (Sample 146-892A-21X-1, 0-24 cm). Long side of photomicrograph is $1.5 \mathrm{~mm}$. See text. 